\title{
Geochemical and isotopic variations in surface waters of the monongahela river basin: An area of accelerating marcellus shale development in West Virginia
}

\author{
Adam J. Pelak \\ West Virginia University
}

Follow this and additional works at: https://researchrepository.wvu.edu/etd

\section{Recommended Citation}

Pelak, Adam J., "Geochemical and isotopic variations in surface waters of the monongahela river basin: An area of accelerating marcellus shale development in West Virginia" (2014). Graduate Theses, Dissertations, and Problem Reports. 408.

https://researchrepository.wvu.edu/etd/408

This Thesis is protected by copyright and/or related rights. It has been brought to you by the The Research Repository @ WVU with permission from the rights-holder(s). You are free to use this Thesis in any way that is permitted by the copyright and related rights legislation that applies to your use. For other uses you must obtain permission from the rights-holder(s) directly, unless additional rights are indicated by a Creative Commons license in the record and/ or on the work itself. This Thesis has been accepted for inclusion in WVU Graduate Theses, Dissertations, and Problem Reports collection by an authorized administrator of The Research Repository @ WVU. For more information, please contact researchrepository@mail.wvu.edu. 


\title{
GEOCHEMICAL AND ISOTOPIC VARIATIONS IN SURFACE WATERS OF THE MONONGAHELA RIVER BASIN: AN AREA OF ACCELERATING MARCELLUS SHALE DEVELOPMENT IN WEST VIRGINIA
}

\author{
Adam J. Pelak \\ Thesis submitted to: \\ the Eberly College of Arts and Sciences \\ at West Virginia University \\ in partial fulfillment of the requirements for the degree of
}

Master of Science

in

Geology

\author{
Dr. Shikha Sharma (Chair) \\ Dr. Joseph Donovan \\ Dr. Timothy Carr \\ Department of Geology and Geography \\ Morgantown, West Virginia \\ 2014
}

Keywords: surface water geochemistry, stable isotope geochemistry, Marcellus Shale Copyright 2014 Adam Pelak 


\title{
ABSTRACT \\ GEOCHEMICAL AND ISOTOPIC VARIATIONS IN SURFACE WATERS OF THE MONONGAHELA RIVER BASIN: AN AREA OF ACCELERATING MARCELLUS SHALE DEVELOPMENT IN WEST VIRGINIA
}

\author{
Adam J. Pelak
}

Water samples were collected from fifty streams in the Monongahela River basin of West Virginia at baseflow condition. The study area was divided into different Marcellus Shale production categories based the amount of Marcellus Shale gas production in a particular HUC12 sub-watershed. All samples were analyzed for selected major and minor geochemistry, as well as stable isotopes of $\delta^{2} \mathrm{H}_{\mathrm{H} 2 \mathrm{O}}, \delta^{18} \mathrm{O}_{\mathrm{H} 2 \mathrm{O}}, \delta^{13} \mathrm{C}_{\mathrm{DIC}}, \delta^{18} \mathrm{O}_{\mathrm{SO} 4}$ and $\delta^{34} \mathrm{~S}_{\mathrm{SO} 4}$. The geochemical and isotopic characteristics of the 50 water samples collected show no clustering based on production category. Extremely high concentrations of total dissolved solids (TDS) are characteristic of produced water from Marcellus Shale production. All of our samples have TDS concentrations less than $1000 \mathrm{mg} / \mathrm{L}$, with a direct correlation between TDS and dissolved sulfate concentration. The area with the greatest density of Marcellus Shale development has also undergone extensive coal mining. Hence geochemical and isotopic characteristics were used to decouple the effects of coal mining from shale gas development in the area. Elevated dissolved sulfate concentrations are interpreted to be the result of contribution from coal mine drainage. The stable isotopic composition of $\delta^{2} \mathrm{H}_{\mathrm{H} 2 \mathrm{O}}$ and $\delta^{18} \mathrm{O}_{\mathrm{H} 2 \mathrm{O}}$ lie along to meteoric water line and show expected trends with altitude indicating that this is meteoric water. The geochemical and isotopic characteristics of the waters also does not indicate that the streams are receiving any significant contribution from produced waters associated with Marcellus Shale drilling or natural structural pathways. However, the water samples collected represent synoptic, or one-time sampling, and continued site-specific monitoring might better assess the impact of shale gas drilling on water quality of streams. 


\section{ACKNOWLEDGEMENTS}

I would like to thank Dr. Joseph Donovan and Dr. Timothy Carr for their advice and support on this thesis. I would especially like to thank Dr. Shikha Sharma for her advice, support, patience, and guidance on this thesis. This thesis would not have been possible without all of your help over the past two years.

I would also like to thank all of the graduate students, professors, and friends that I have met over the past several years in the Department and in Morgantown. It has been a rewarding and challenging endeavor that is only made possible by the help and friendship of others.

A very big thank you to the staff of the USGS West Virginia Water Science Center in Charleston, WV (Jeremy White, Doug Chambers, Katherine Paybins, Terry Messinger, \& Hugh Bevans) for helping with fieldwork and making this research possible.

I would especially like to thank my parents, Richard and Barb Pelak, for their endless love and support, without whom I would not have been able to make it to where I am today.

I tell you folks, it's harder than it looks... 
TABLE OF CONTENTS

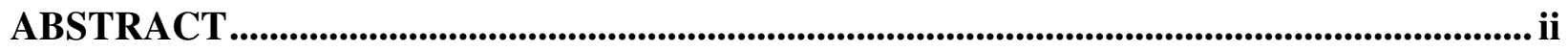

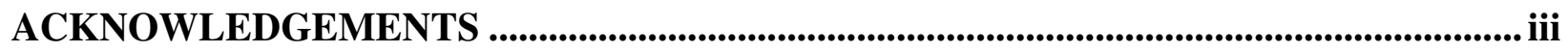

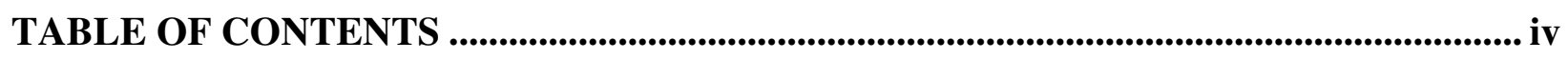

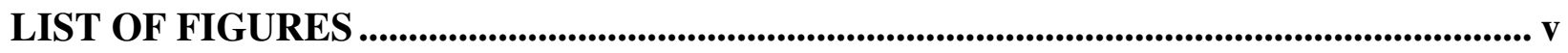

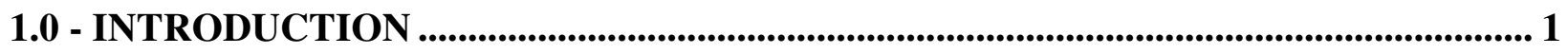

1.1-STUDY AREA BACKGROUND AND SITE SELECTION .....................................5

1.1.1 - GEOCHEMISTRY OF SURFACE WATERS IN THE MONONGAHELA

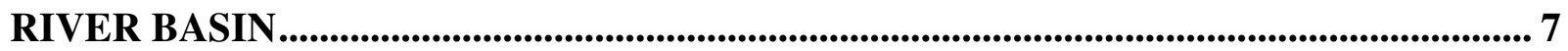

1.1.2 - STABLE ISOTOPES OF OXYGEN AND HYDROGEN IN WATER ................. 11

1.1.3 - STABLE ISOTOPES OF CARBON IN DISSOLVED INORGANIC CARBON. 13 1.1.4 - STABLE ISOTOPES OF SULFUR AND OXYGEN IN DISSOLVED SULFATE

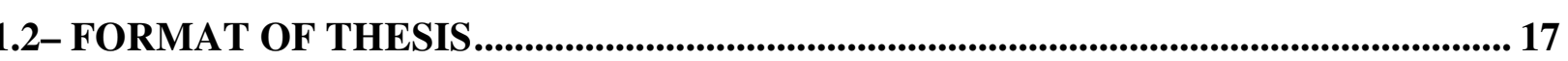

2.0 - GEOCHEMICAL AND ISOTOPIC VARIATIONS IN SURFACE WATERS OF THE MONONGAHELA RIVER BASIN: AN AREA OF ACCELERATING MARCELLUS SHALE DEVELOPMENT IN WEST VIRGINIA......................................... 18

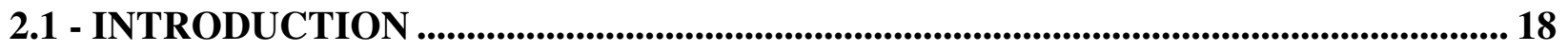

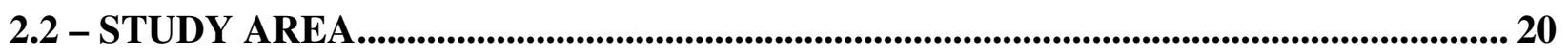

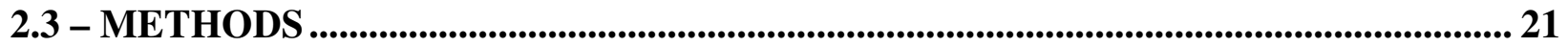

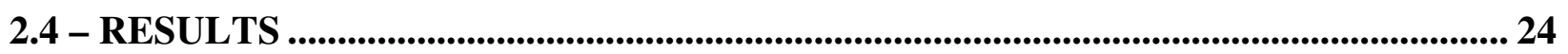

2.5 - DISCUSSION

2.5.1 - SURFACE WATER GEOCHEMISTRY ................................................................. 25

2.5.2 - OXYGEN AND HYDROGEN ISOTOPES ............................................................ 29

2.5.3 - CARBON ISOTOPES OF DISSOLVED INORGANIC CARBON..................... 30

2.5.4 - SULFUR AND OXYGEN ISOTOPES OF DISSOLVED SULFATE ................... 32

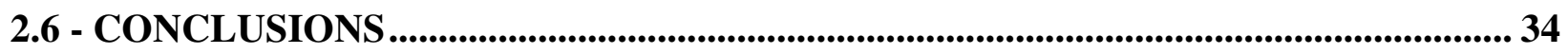

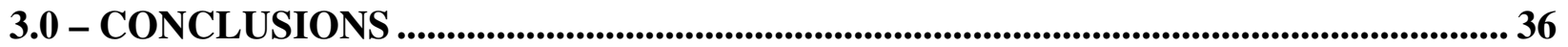

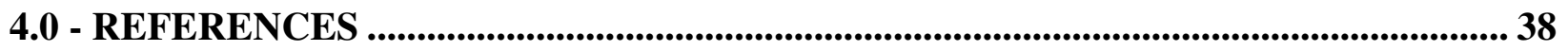

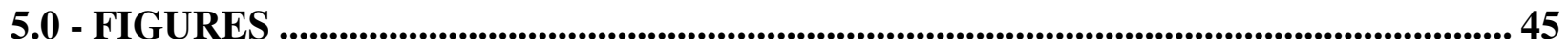

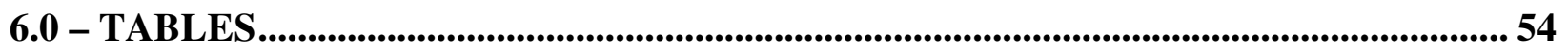




\section{LIST OF FIGURES}

FIGURE 1 - Study area showing sample locations, HUC-12 watersheds of samples and Marcellus Shale Production categories, as well as all HUC-12's in the Monongahela River basin of West Virginia.

FIGURE 2 - Deviations from the global meteoric water line (GMWL) and the processes affecting deviations 46

FIGURE 3 - End-member contributions to overall $\delta^{13} \mathrm{C}$ in dissolved inorganic carbon ...... 47

FIGURE 4 - Piper Diagram for all sample locations, subdivided by Marcellus Shale production category 48

FIGURE 5 - Total dissolved solids (mg/L) versus dissolved sulfate $(\mathrm{mg} / \mathrm{L})$ for all sample locations, subdivided by Marcellus Shale production category. 49 FIGURE 6 - $\delta^{18} \mathrm{O}_{\mathrm{H} 2 \mathrm{O}}$ values (\%o - VSMOW) versus $\delta^{2} \mathrm{H}_{\mathrm{H} 2 \mathrm{O}}$ values (VSMOW) for all sample locations, subdivided by Marcellus Shale production category. LMWL denotes the local meteoric water line.

FIGURE 7 - Box and whisker plot of $\delta^{13} C_{\text {DIC }}$ (\%o - VPDB) for all sample locations, subdivided by Marcellus Shale production category.

FIGURE 8 - $\delta^{18} \mathrm{O}_{\mathrm{SO} 4}\left(\%\right.$ - VSMOW) versus $\delta^{34} \mathrm{~S}_{\mathrm{SO} 4}(\%$ - VCDT) values for all samples, subdivided by Marcellus Shale production category

FIGURE 9 - Cl (mg/L) versus $\mathrm{Cl} / \mathrm{Br}$ molar ratio for all sample locations, subdivided by Marcellus Shale production category 


\section{LIST OF TABLES}

TABLE 1 - Analytical Results.........................................................54-61

TABLE 2 - Water facies and their occurrence in each production category.................52 


\section{0 - INTRODUCTION}

Natural gas is one of the most important energy sources consumed worldwide, and represents nearly one-quarter of total global fossil fuel consumption. According to the U.S. Energy Information Administration, natural gas is the world's most rapidly growing fossil fuel, and consumption is increasing at an annual rate of $1.6 \%$ (U.S. EIA, 2012). Natural gas is seen as an attractive alternative to other conventional energy sources such as oil and coal due to its comparatively lower carbon emissions. As of 2010, natural gas contributed approximately $15.5 \%$ to power generation for electricity in the United States. The use of natural gas for power generation for electricity has been increasing annually due to its currently (2014) lower price comparable to other sources of power. A 2011 paper by Lu et al. found that during the period from 2008-2009 the use of natural gas for electricity generation in the U.S. lead to a decrease in the emission of $\mathrm{CO}_{2}$ in to the atmosphere ( $\mathrm{Lu}$ et al., 2012). The United Nations predicts that world population will increase to 9.3 billion by 2050 , with most of the growth occurring in less developed regions of the world (U.N., 2011) This large population growth will see large growth in demand for energy, and natural gas is currently seen as a major component of the global energy picture.

Geologic sources for natural gas can be divided in to two main categories, conventional and unconventional. Conventional sources consist of a permeable rock such as sandstone that allows for the gas to be extracted from it by the construction of a vertical well in to a permeable rock reservoir. Natural gas is contained in the rock reservoir due to migration from an organic-rich source rock, most commonly shale. Conventional reservoirs allow for extraction of gases because the permeability of the reservoir rock allows for migration and flow of natural gas between interconnected pores in the rock. Unconventional sources consist of a low permeability 
rock such as shale that needs to be fractured in order to stimulate permeability in the source rock to release the natural gas. In the past decade, the technology to recover unconventional sources of natural gas in shale rock reservoirs was developed, and is known as hydraulic fracturing. Hydraulic fracturing is performed by injecting a fluid mixture of water and chemicals at high pressures to create fractures in a target geologic formation. After the rock is fractured, internal pressures of the formation cause the fracturing fluid, some formation waters, and corresponding natural gas to return to the surface. If the pressures are not sufficient, a submersible pump may be installed to aid in the recovery of the natural gas and fracturing fluids (EPA, 2011). In addition to hydraulic fracturing, the recovery of unconventional sources of natural gas is often aided by the process of horizontal drilling, also known as directional drilling. Horizontal drilling allows for a single well pad to deploy multiple horizontal wells from a central location. Each of these wells can reach up to several thousands of feet horizontally from the well pad.

Unconventional sources of natural gas include shale gas, tight sand gas, and coalbed methane. In the past decade, shale gas development has grown dramatically, and several onshore unconventional sources of shale gas have begun to be developed in the United States and around the world. The U.S. Energy Information Administration (2011) identified 48 important shale gas plays in 32 selected countries around the world. Their estimates of total recoverable natural gas in these selected plays plus those in the United States put total recoverable natural gas at 6,622 trillion cubic feet. Important shale gas plays include the Barnett Shale, the Fayetteville Shale, and the Marcellus Shale. Shale gas contributed approximately $23 \%$ of all U.S. natural gas production in 2010, and is projected to increase to approximately $49 \%$ of production by 2035 (U.S. EIA 2012). The Marcellus Shale play is the largest shale gas play in the United States, and as such is an integral part of the overall shale gas picture for the United States. It is located in the 
states of New York, Pennsylvania, West Virginia, and Ohio, and covers an area of 95,000 square miles. The Marcellus Shale is a highly organic Middle Devonian black shale that is interbedded with medium-gray silty shale and dark gray limestones. Depths for the Marcellus Shale range from 9,000 feet at its deepest to outcropping at the surface along the northern and eastern edges of the formation. Production occurs at depths ranging from 4,000 feet to 8,500 feet. The average thickness ranges from 50 feet to 100 feet, but can be as thick as over 350 feet in places at its thickest and thins out along its edges (Bruner \& Smosna, 2011). Estimates of the total recoverable amount of natural gas contained in the Marcellus Shale vary. The USGS reported in 2011 that they estimate the Marcellus Shale contains 84 trillion cubic feet of recoverable natural gas. However, in 2012, the U.S. Department of Energy estimated that the Marcellus Shale contains 141 trillion cubic feet of recoverable natural gas. These estimates will likely change as the technology to extract natural gas improves.

Hydraulic fracturing and horizontal drilling are the two key technologies that are used to extract natural gas from the Marcellus Shale. Horizontal drilling involves the construction of a vertical well to the depth above the target formation. The well angle is gently angled until it is at an angle of 90 degrees from the vertical well. The horizontal section of the well may extend for several thousand feet from the vertical section of the well. The wellbore is cased from the surface through the vertical and horizontal portions of the well. The well is completed with several series of casings that extend below the water table. Once the well is completed, the horizontal section of the well is perforated in several sections in the target formation. Hydraulic fracturing involves the injection of a mixture of water, sand, and chemicals under intense pressure to create fractures in the target formation. After hydraulic fracturing of the well has been completed, the produced water and natural gas of the target formation flows to the surface due to pressure differentials 
between the target formation and the surface, or can be returned to the surface by use a submersible pump. The amount of water that returns as produced water is different for every well, but averages approximately $20 \%$ of the initial injected volume (Engelder, 2012).

There are concerns that water withdrawals for hydraulic fracturing and chemicals added to the fracturing fluid can adversely impact the water quantity and quality of our fresh water resources. A single well is estimated to use an average of 5 million gallons of fresh water during its production lifetime (Gregory et al. 2011). Water and sand normally comprise approximately $98 \%$ of the composition of hydraulic fracturing fluid, and common additions to the sand and water mixture include organic chemicals such as friction reducers, biocides, scale inhibitors, acid inhibitors and surfactants (Arthur et al. 2009; Soeder and Kappel 2009; Chapman et al. 2012) However, the chemical constituents of each fracturing fluid vary from well to well depending on local well conditions. Groundwater associated with deep formations tend to have very high concentration of total dissolved solids (TDS) in excess of $250,000 \mathrm{mg} / \mathrm{L}$, naturally occurring radioactive materials, and trace levels of toxic elements (Osborn et al. 2011; Chapman et al. 2012; Warner et al. 2012) . Also, the process of creating a well pad for natural gas drilling often involves land clearing, which can lead to enhanced sediment run-off to surface waters. In 2008, the West Virginia Department of Environmental Protection passed the Water Resources Protection Act, which requires registration for surface water or groundwater withdrawals of 750,000 gallons during a period of one calendar month. Operators are required to identify the amount of water to be used, the time period for withdrawal, the location of all water sources, the types of water to be used, the volume of each water type being used, the location of water impoundments, disposal location, and disposal methods (Arthur et al., 2011). 
After the hydraulic fracturing process is completed, natural gas is either stored or transferred to market by pipeline, and the produced water is stored on-site near the well-pad in steel storage tanks or artificially created storage ponds until it can be transferred off-site by truck to a disposal facility. There is public concern that migration from the fractured Marcellus Shale, infiltration from leaky storage ponds, steel tanks, or runoff can contaminate the groundwater or local surface water resources. Additionally, accidents by tanker trucks containing produced water can lead to spills. Surface water that has been contaminated with hydraulic fracturing produced water can have both short-term and long-term effects. The geochemistry of surface waters affected by contamination by produced waters will depend on the amount, exposure, and types of fluids that reach surface waters.

\section{1 - STUDY AREA BACKGROUND AND SITE SELECTION}

The Monongahela River Basin in West Virginia and Pennsylvania is currently undergoing extraction of natural gas from the Marcellus Shale. The Monongahela River is formed by the confluence of the West Fork and Tygart Valley rivers near Fairmont, West Virginia, and flows north for 137 miles to Pittsburgh, Pennsylvania, where it joins with the Allegheny River to form the Ohio River. The Monongahela River basin lies entirely within the Appalachian Plateau physiographic province and has a drainage basin of 7,340 square miles. In addition to recent natural gas development, the Monongahela River Basin has long been an of area surface and underground coal mining, conventional natural gas drilling, logging, agriculture, and many industrial activities. As of September 2012, 252 wells had been completed Marcellus Shale (WVGES, 2012).

In this study, all of the 118 sub-watershed units (HUC-12's) in the portion of the Monongahela River Basin in West Virginia were analyzed for their current state of Marcellus Shale production 
activity. HUC-12's in the Monongahela River basin were divided in to five categories that represent different degrees of production of Marcellus Shale in each HUC-12. These five categories are high production ( $>1,000 \mathrm{MCF} / \mathrm{mi}^{2} /$ year), low production $\left(<1,000 \mathrm{MCF} / \mathrm{mi}^{2} /\right.$ year), near high production (adjacent to high production HUC-12), near low production (adjacent to low production HUC-12), and no production (underlain by Marcellus Shale greater than 50 feet thick). 50 sample sites chosen were distributed within each category in proportion to the ratio of their area in the Monongahela River basin. Sample sites were also limited to those which had been previously sampled by the USGS. In all, 45 HUC-12's were selected for analysis in this study. Figure 1 shows all sample locations, as well as HUC-12 production category.

Published literature (Chapman et al., 2011; Sharma et al. 2011; Warner et al. 2012) indicates that produced waters have different geochemical and isotopic characteristics compared to regional surface waters. Hence, it is hypothesized that comparison of isotopic and geochemical characteristics of the 5 production categories outlined above can help in understanding if the surface water in areas of high production of Marcellus Shale are receiving significant contribution from produced water due to changes in hydrologic connections associated with Marcellus Shale development. Also, geochemical and isotopic variations in surface waters could be the result of improper disposal of produced water from Marcellus Shale development. All sites were sampled at or near baseflow conditions to ensure all contributions to surface water flow are from groundwater. Surface water in the Monongahela River basin can also be influenced by deeper groundwater, underground coal mine water, surface coal mine water, industrial water pollution, agricultural inputs, and general land disturbances. In addition to standard geochemical analysis for major anions, cations, trace elements, radioactive chemistry, and related parameters $(\mathrm{pH}$, specific conductance, Eh, temperature, total dissolved solids, 
dissolved oxygen, turbidity, alkalinity), we hypothesize that the use of stable isotope analysis of surface waters in the Monongahela River basin will allow for the establishment of a unique geochemical fingerprint in five categories of Marcellus Shale development.

\subsection{1 - GEOCHEMISTRY OF SURFACE WATERS IN THE MONONGAHELA RIVER}

\section{BASIN}

The geochemistry of surface waters in the Monongahela River basin is affected by several inputs. Coal mine drainage and produced water from the process of hydraulic fracturing could be the two major contributors to salinity of the fresh waters of the region. Each of these two sources should have distinct geochemical signatures, such as high concentrations of $\mathrm{Na}, \mathrm{Br}$, and $\mathrm{Cl}$, for produced water and high concentrations of $\mathrm{SO}_{4}, \mathrm{Fe}, \mathrm{Al}$, and $\mathrm{Mn}$ for acid mine drainage. However, high total dissolved solid values can be the result of contamination by road salt, industrial discharges, wastewater effluent from septic systems, erosion of land surfaces due to well pad construction, or brines seeping in from deep geologic formations into shallow freshwater sources through natural faults and fractures over millions of years. The three most important factors affecting surface water geochemistry are the type of geologic material that is present in the basin, how long the water is in contact with that material, and the geochemistry of the precipitation that falls in the watershed. The main chemical reactions that affect the overall geochemistry of surface water in the basin are: mineral precipitation/dissolution, sorption/ionexchange, acid-base, oxidation/reduction, dissolution/ex-solution of gases, and biodegradation (Drever, 1997). The watershed in the basin is dominated by agricultural and forested land, and underground and surface coal mining has a long history in the watershed dating back to the $19^{\text {th }}$ century. Input sources to the river basin can be classified as either point sources or nonpoint sources. Point sources are specific discharges in to surface water such as pipes, conduits, landfill 
leachate collection systems, mine drainage, or wastewater treatment plants. In the U.S., permits are required for the discharge of point sources in to surface water through the National Pollutant Discharge Elimination System (NPDES), and are classified in to non-mining and mining point sources. There are several abandoned mine treatment facilities located in the Monongahela River basin that contribute large discharges to the watershed. Nonpoint sources are contributions to surface water from diffuse sources, such as rainfall runoff. Nonpoint sources are grouped in to three categories: abandoned mine lands (AML), revoked mines, and forest, agricultural, barren, or urban lands. (EPA 2002)

To examine the geochemistry of surface waters, samples were analyzed for major cations and anions, trace elements, radiochemistry, and related parameters ( $\mathrm{pH}$, specific conductance, Eh, temperature, total dissolved solids, dissolved oxygen, turbidity, and alkalinity). A piper diagram is a common way of distinguishing water sources based on their relative proportions of their major ions. A piper diagram is a combination of trilinear diagrams that show the percent composition of major cations and anions present in a water sample. The most common ions found in natural waters are $\mathrm{K}, \mathrm{Ca}, \mathrm{Mg}, \mathrm{Na}, \mathrm{CO}_{3}, \mathrm{SO}_{4}, \mathrm{HCO}_{3}$, and $\mathrm{Cl}$. The peak of each trilinear diagram represents $100 \%$ composition of each cation or anion. Piper diagrams are also useful to determine the composition of a water sample that can be attributed to mixing between two endmembers.

Total dissolved solids (TDS) in surface water represent the dissolved concentration of common anions and cations such as $\mathrm{Cl}, \mathrm{HCO}_{3}, \mathrm{SO} 4, \mathrm{Ca}, \mathrm{Na}, \mathrm{Mg}, \mathrm{K}$, and others that can pass through a filter that is smaller than 2 microns. TDS concentrations are often measured in $\mathrm{mg} / \mathrm{L}$ and the US EPA has set secondary guidelines for TDS in surface water at $500 \mathrm{mg} / \mathrm{L}$. Produced water from hydraulic fracturing operations in the Marcellus Shale show extremely high concentrations of 
TDS $(20,000-250,000 \mathrm{mg} / \mathrm{L})$ (Haluszczak et al., 2013). The source of the salinity in the produced water from Marcellus Shale operations is thought to be from the deep saline formation brines in the Marcellus Formation, overlying Upper Devonian brines, or underlying Lower Devonian and older brines. Appalachian brines formed from evaporation of seawater that altered to varying degrees in different deep formations in the Appalachian Basin. All brines underwent evaporation of seawater past the point of halite saturation, which results in brines with low $\mathrm{Na} / \mathrm{Cl}$ and high $\mathrm{Cl} / \mathrm{Br}$ ratios relative to seawater. Dolomitization of the brines in carbonate rocks leads to enriched $\mathrm{Ca}$ and depleted $\mathrm{Mg}$ concentrations relative to seawater. Distinct ratios of $\mathrm{Ba} / \mathrm{Sr}$, $\mathrm{Sr} / \mathrm{Ca}, \mathrm{Li} / \mathrm{Cl}, \mathrm{Ba} / \mathrm{Cl}$, and $\mathrm{Sr} / \mathrm{Cl}$ in Appalachian brines can be used to distinguish the formation source. Produced water from the Marcellus Formation is characterized by high activities of Ra $\left(1,500-3,000 \mathrm{pCi} / \mathrm{L}\right.$ and low ${ }^{228} \mathrm{Ra} /{ }^{226} \mathrm{Ra}$ ratios (0.12-0.72) (Warner et al., 2012).

In 2008, high levels of TDS in the Pennsylvania portion of the Monongahela River were attributed to wastewater treatment plants disposal of Marcellus Shale produced water (Kargbo et al., 2010) Since 2009, wastewater treatment plants are no longer permitted to accept Marcellus Shale produced water for treatment. Marcellus Shale produced water can also enter the watershed though leaks in holding ponds that infiltrate in to shallow groundwater, by truck spills carrying produced water, and failures of well construction that can lead to contamination of shallow aquifers. High TDS values were also seen as the contributing cause of a fish kill in Dunkard Creek in September 2009, which was attributed to coal mine discharges. (Renner 2009; Brooks et al., 2011; Chapman et al., 2012).

To help distinguish sources of TDS in surface water, $\mathrm{Cl}$ and $\mathrm{Br}$ concentrations in dissolved waters are useful as natural tracers for sources of salinity due to their conservative nature and limited water-rock interaction. The ratio of $\mathrm{Cl}$ to $\mathrm{Br}$ is often useful in showing unique sources of 
salinity such as seawater intrusion, brine intrusion, and dissolution of evaporate minerals (Vengosh and Pankratov 1998; Freeman 2007; Alcalá and Custodio 2008). Plots of elemental ratios of $\mathrm{Ca} / \mathrm{Cl}$ versus $\mathrm{Cl}, \mathrm{Si} / \mathrm{Cl}$ versus $\mathrm{Cl}, \mathrm{Na} / \mathrm{Cl}$ versus $\mathrm{Cl}, \mathrm{Mg} / \mathrm{Cl}$ versus $\mathrm{DIC}, \mathrm{K} / \mathrm{Cl}$ versus DIC, and $\mathrm{Ca} / \mathrm{DIC}$ can be used to elucidate rock weathering, ion exchange, and sources of salinity in groundwater. Concentrations of TDS versus ratios of $\mathrm{Na} /(\mathrm{Na}+\mathrm{Ca})$ and ratios of $\mathrm{Cl} /\left(\mathrm{Cl}+\mathrm{HCO}_{3}\right)$ can also be used to understand evolution of water types, evaporation, and precipitation. Calculation of the saturation index of dolomite, calcite, and silicate can additionally provide information as to the dominant reactive mineralogy present which can be used in conjunction with plots of elemental ratios and TDS to determine dominant water-rock interactions at each sample location (Wen et al., 2005; Cartwright et al., 2007).

As a consequence of coal mining, mine drainage is a prevalent source of contamination to surface water and groundwater in the Monongahela River basin. Mine drainage occurs when surface or groundwater comes in contact with the mineral pyrite (iron sulfide) in coal and waste rock from mining. When pyrite is exposed to water and air, the sulfur is oxidized and releases ferrous iron ions $\left(\mathrm{Fe}^{2+)}\right.$ Also, this reaction releases hydrogen ions $\left(\mathrm{H}^{+}\right)$which contribute acidity to the system. This reaction can lead to further reactions that will produce ferric hydroxide, sulfuric acid, and additional acidity.

The series of reactions that lead to AMD can also lead to secondary reactions of sulfuric acid with other minerals in the coal and mine spoil that produce high concentrations of aluminum, and manganese. Acidity is generated only if alkalinity in the system is exceeded by the acidity. The most common sources of alkalinity in natural waters are calcite and dolomite. Dissolution of aluminosilicate minerals can also make a neutralization contribution to acid mine drainage 
affected waters; however the rates of dissolution are slower than carbonates (Banks et al., 1997; Sams III and Beer 2000).

Surface water and groundwater that comes in contact with coal and mine waste can either be acidic or alkaline. Acidic coal mine drainage has low $\mathrm{pH}(<4.0)$ and has elevated concentrations are sulfate, iron, manganese, aluminum, and other constituents. Alkaline coal mine drainage has neutral to alkaline $\mathrm{pH}(>7.0)$ but can still contain elevated concentrations of sulfate, iron, manganese, and other constituents. The most reliable indicator of mine drainage contaminated waters is sulfate. Sulfate has a high solubility and is considered conservative at $\mathrm{pH}$ levels found in natural waters (Sams III and Beer 2000).

\subsection{2 - STABLE ISOTOPES OF OXYGEN AND HYDROGEN IN WATER}

The stable isotopes of hydrogen and oxygen in water, $\delta^{2} \mathrm{H}$ and $\delta^{18} \mathrm{O}$, respectively, can provide a fingerprint of the water source due to meteorological processes. These isotopes are extremely useful because of their conservative nature in the hydrologic cycle. The ratios of $\delta^{2} \mathrm{H}$ and $\delta^{18} \mathrm{O}$ occur at a predictable relationship due to physical and chemical processes that cause fractionation of isotopes due to evaporation and condensation. When this predictable relationship between $\delta^{2} \mathrm{H}$ and $\delta^{18} \mathrm{O}$ is graphed, it is known as the global meteoric water line (GMWL), and is defined by the equation $\delta^{2} \mathrm{H}=8.13 * \delta^{18} \mathrm{O}+10.8 \%$ (Craig, 1961). As water evaporates from the ocean and an air mass moves inland, water leaves the air mass in the form of precipitation. The precipitation that falls first will be enriched in the heavier isotopes, and as the air mass moves farther inland, the precipitation will be depleted in the heavier isotopes. Factors that influence the global distribution of $\delta^{2} \mathrm{H}$ and $\delta^{18} \mathrm{O}$ in precipitation include latitude, longitude, temperature, distance to coastline, elevation, amount of precipitation, and evaporation (Dansgaard 1964; Rozanski et al., 1993; Gat 1996; Fricke and O’Neil 1999; Kendall and Coplen 2001). 
The process of Rayleigh distillation causes the discrepancy seen on Figure 2 between cold and warm regions, which is due to secondary evaporation during precipitation. The slope of the graph is attributed to relative humidity, and the GMWL assumes a relative humidity of $85 \%$. In more arid regions with lower humidity however, there is secondary evaporation as precipitation is falling which causes the slope of the line to lessen. Secondary fractionation factors can also alter the isotopic composition of $\delta^{2} \mathrm{H}$ and $\delta^{18} \mathrm{O} . \delta^{2} \mathrm{H}$ and $\delta^{18} \mathrm{O}$ values often see a shift to a position below the local meteoric water line due to climatic and subsurface processes. In some low humidity regions, re-evaporation of precipitation from surface waters can create precipitation that that plots above the LMWL (Figure 2). The calculation of deuterium excess (d-excess), defined as $d=\delta^{2} \mathrm{H}-8^{*} \delta^{18} \mathrm{O}$, allows for the estimation of the addition of ground sources of water to precipitation (Clark \& Fritz, 1997).

Because surface waters are a heterogeneous mixture of several sources of water, hydrogen and oxygen isotopes of water can be used to help understand where surface water is receiving inputs from. The main sources of water to streams are precipitation, groundwater, and surface/shallow subsurface runoff. The percent contribution by these sources to surface water will primarily be dependent on climatic factors, size of the stream, and human activities in the watershed. The isotopic composition of groundwater is very similar the initial precipitation that infiltrated to the water table. There are water-rock interactions that can occur between groundwater and minerals present in a geologic formation. Mineral dissolution and re-precipitation, mineral alteration, and isotope exchange between water and the mineral crystal lattice are all processes that can affect the isotopic composition of the water molecule. Water that reaches surface water from runoff is also similar to that of precipitation, but can be altered when precipitation is trapped on vegetation and secondary evaporation occurs. In this case, the type of vegetation, duration, intensity, and 
intermittency of precipitation will all be factors in determining isotopic composition (Clark and Fritz 1997; Diefendorf and Patterson 2005; Dutton et al., 2005; Gibson et al., 2005; Lambs et al., 2005; Schulte et al., 2011).

$\delta^{2} \mathrm{H}$ and $\delta^{18} \mathrm{O}$ values for produced water associated with hydraulic fracturing have been analyzed from a few Marcellus Shale wells in Greene County, PA (Sharma et al., 2011). Also, the $\delta^{2} \mathrm{H}$ and $\delta^{18} \mathrm{O}$ values for Appalachian formation brines have also been analyzed by several researchers (Warner et al., 2012). The stable isotope composition in $\delta^{2} \mathrm{H}$ and $\delta^{18} \mathrm{O}$ in produced waters and deep formation brines show enriched values compared to shallow groundwater and precipitation. The source of the formation brine is likely connate seawater that has been isotopically modified over millions of years through evaporation and rock water interaction. The $\delta^{18} \mathrm{O}$ values are more enriched compared to ${ }^{2} \mathrm{H}$ and show a shift toward the right of the GMWL due to multiple processes including rock-water interactions such as gypsum dehydration, ${ }^{18} \mathrm{O}$ exchange with carbonate minerals, and shale membrane filtration. By comparing the values of $\delta^{2} \mathrm{H}$ and $\delta^{18} \mathrm{O}$ for the five production categories of Marcellus Shale development of surface waters at baseflow in the Monongahela River basin, any deviations from the LMWL can be analyzed for possible contributions other than shallow groundwater. $\delta^{2} \mathrm{H}$ and $\delta^{18} \mathrm{O}$ in $\mathrm{H}_{2} \mathrm{O}$ have also been used to identify contributions from different aquifers in several studies (Connolly et al., 1990; Kharaka and Thordsen 1992; Williams 1997; Chunfang et al., 2001; Maekawa et al., 2006; Gammons et al., 2010; Dresel and Rose 2010). Warner et al. (2012) indicate that to see any noticeable shift in $\delta^{2} \mathrm{H}$ and $\delta^{18} \mathrm{O}$, a contribution of at least $20 \%$ produced water is needed.

\subsection{3 - STABLE ISOTOPES OF CARBON IN DISSOLVED INORGANIC CARBON}

The main sources of carbon found in natural waters are from mineral dissolution of carbonates and silicates, oxidation of organic matter, or from atmospheric carbon dioxide that dissolves into 
water. Dissolved inorganic carbon (DIC) is comprised of the dissolution of carbonate and silicate minerals and dissolution of $\mathrm{CO}_{2}$. Dissolved organic carbon (DOC) is comprised of the oxidation of dissolved organic matter by aerobic bacteria. Particulate inorganic carbon (PIC) is comprised primarily of $\mathrm{CaCO}_{3}$. Globally, rivers carry an estimated $0.3-0.6 * 10^{15}$ tons of carbon per year to the world's oceans. Of that total, 45\% consists of DIC and 15\% consists of PIC (Rozanski et al., 2001). The research presented here will examine only the $\delta^{13} \mathrm{C}$ contribution by DIC. DIC found in natural waters is composed of carbonic acid $\left(\mathrm{H}_{2} \mathrm{CO}_{3}\right)$, bicarbonate $\left(\mathrm{HCO}_{3}\right)$, carbonate $\left(\mathrm{CO}_{3}\right)$, and dissolved $\mathrm{CO}_{2}$. The distribution of each species is primarily a function of $\mathrm{pH}$.

The isotopic signature of $\delta^{13} \mathrm{C}$ found in natural waters depends on several factors, including type of vegetation present in the watershed, carbonate and silicate weathering, groundwater contribution, and atmospheric exchange. In surface waters the main sources of DIC are decay of organic matter, carbonate dissolution, and atmospheric invasion of $\mathrm{CO}_{2}(\mathrm{~g})$. As $\mathrm{CO}_{2}(\mathrm{~g})$ diffuses through soil and into groundwater, it hydrates and dissociates to form the four species that comprise total DIC:

$\mathrm{CO}_{2}(\mathrm{~g})+\mathrm{H}_{2} \mathrm{O}<-->\mathrm{H}_{2} \mathrm{CO}_{3}<-->\mathrm{H}^{+}+\mathrm{HCO}^{3-}<-->2 \mathrm{H}^{+}+\mathrm{CO}_{3}{ }^{2-}$

Each aqueous species has a different fractionation factor associated between it and the soil gas. The dominant carbonate species found in natural waters that contribute to DIC are bicarbonate and carbonate. Additionally, decay of organic matter contributes DIC to natural waters, but its isotopic contribution of $\delta^{13} \mathrm{C}$ will be dependent on the type of vegetation present. There are two types of vegetation, $\mathrm{C} 3$ and $\mathrm{C} 4$ plants, whose organic matter decay and roots respiration, lead to the formation of soil $\mathrm{CO}_{2}$. There is a difference in the fractionation factors of how $\mathrm{C} 3$ plants (about $-20 \%$ ) and $\mathrm{C} 4$ plants (about $-4 \%$ ), absorb atmospheric $\mathrm{CO}_{2}$ that leads to each having a 
distinct isotopic signature. However, there is little to no fractionation during their subsequent decay and roots respiration. This leads to soil $\mathrm{CO}_{2}$ with $\delta^{13} \mathrm{C}$ contributions from $\mathrm{C} 3$ plants around $-21 \%$ and from C4 plants around $-8 \%$ (Brunet et al., 2005). Also, seasonal and temporal variations in DIC and $\delta^{13} \mathrm{C}$ have been shown in previous studies (Atekwana and Krishnamurthy 1998; Hillaire-marel et al., 2002; Doctor et al., 2008). End-member contributions to total DIC found in natural waters will ultimately control the overall $\delta^{13} \mathrm{C}$ composition of the water. (Figure 3)

In the Monongahela River basin, there are several inputs that can alter the expected value of surface water $\delta^{13} \mathrm{C}_{\mathrm{DIC}}$. The dominant sources of DIC to surface water baseflow will be from water-rock interaction, rock weathering, and decay of organic matter. The $\delta^{13} \mathrm{C}_{\mathrm{DIC}}$ values can be used in conjunction with geochemistry to understand rock weathering and dissolution reactions such as carbonate dissolution, silicate dissolution, organic matter decay, and atmospheric exchange, which are dominant in the subsurface and contribute DIC to surface waters. Enrichment of $\delta^{13} \mathrm{C}_{\text {DIC }}$ in conjunction with elevated TDS values and high DIC concentrations can be indicative of carbonate dissolution. Dolomite dissolution may have a positive correlation between $\mathrm{Mg}$ concentrations and $\delta^{13} \mathrm{C}_{\text {DIC }}$ values (Rueedi et al., 2006; Atekwana and Fonyuy 2009; Schulte et al., 2011). Co-produced water from coalbeds where biogenic methanogenesis is prominent have been shown to have values enriched in $\delta^{13} \mathrm{C}_{\text {DIC }}$ (Sharma and Frost 2008; McLaughlin et al., 2011). Most of the coals in West Virginia are thermally mature hence the methane is likely to be thermogenic. Therefore, $\delta^{13} \mathrm{C}_{\text {DIC }}$ values are expected only in coalbeds where there is secondary phase of biogenic methane production. Sulfuric acid enhanced carbonate dissolution can result in $\delta^{13} \mathrm{C}_{\text {DIC }}$ enrichment mine drainage waters of the region. Carbonate enhanced dissolution is not likely to result in $\delta^{13} \mathrm{C}_{\mathrm{DIC}}$ values $>+1 \%$; unlike biogenic 
methanogenesis which can result in $\delta^{13} \mathrm{C}_{\mathrm{DIC}}$ values $>+10-30 \%$. Currently, studies are underway at the WVU Stable Isotope Facility to determine if $\delta^{13} \mathrm{C}_{\text {DIC }}$ values of produced water associated with hydraulic fracturing has unique carbon isotopic signatures that can be used in conjunction with other isotopes to track its fate.

\subsection{4 - STABLE ISOTOPES OF SULFUR AND OXYGEN IN DISSOLVED SULFATE}

The three major forms of sulfur in the environment are dissolved sulfate $\left(\mathrm{SO}_{4}\right)$, dissolved sulfide (HS), and hydrogen sulfide gas $\left(\mathrm{H}_{2} \mathrm{~S}\right)$. Sulfur has four oxidation states that make it both an electron donor and acceptor. Sulfur is also a common atmospheric constituent and a byproduct of industrial processes that can lead to the formation of acid rain. Sulfate in the surface waters of the Monongahela River basin is common, due primarily to the oxidation of pyrite. The principle stable isotope of sulfur is $\delta^{34} \mathrm{~S}$, and its values are used in conjunction with $\delta^{18} \mathrm{O}$ to determine sources of sulfate in the environment. Sulfur isotope values exhibit a very wide range of values.

In surface waters, $\delta^{34} \mathrm{~S}$ values are known to have seasonal variations (Trembaczowski et al., 2004) that are related to the source of the sulfur and fractionation related to the oxidation mechanisms (Toran and Harris, 1989). The reactant components $\left(\mathrm{H}_{2} \mathrm{O}, \mathrm{S}\right.$, and $\left.\mathrm{O}_{2}\right)$ are the main determining factor that controls that oxygen isotope composition.

Stable isotopes of sulfur can elucidate the source and type of oxidation that is occurring with respect to pyrite $\left(\mathrm{O}_{2}\right.$ versus $\left.\mathrm{Fe}^{3+}\right)$, and if that oxidation is bacteria driven or abiotic in nature. The oxygen in $\mathrm{SO}_{4}{ }^{2-}$ is derived from atmospheric oxygen or from water, and therefore can help distinguish mechanisms of oxidation. Many studies on the $\delta^{34} \mathrm{~S}$ and $\delta^{18} \mathrm{O}$ composition of sulfate in acid mine drainage have been done (Toran and Harris 1989; Taylor et al., 1984; Gammons et al., 2010), as well as other studies on the fraction of many sulfide minerals (Seal et al., 2000; 
Seal 2006 ). The highest rates of fractionation of $\delta^{34} \mathrm{~S}$ and $\delta^{18} \mathrm{O}$ in dissolved sulfate occur during sulfate reduction. Because AMD inputs in to the Monongahela River basin are widespread, the interpretation of $\delta^{34} \mathrm{~S}$ and $\delta^{18} \mathrm{O}$ in dissolved sulfate will be extremely important. Stable isotopes of dissolved sulfate have also been used in several studies as a way to delineate sources of $\mathrm{SO}_{4}$ between different groundwaters. Sulfate in reducing systems tend to display enriched values of $\delta^{34} \mathrm{~S}_{\mathrm{SO} 4}$ versus oxidizing systems due to preferential use of the lighter ${ }^{32} \mathrm{~S}$ during bacterial $\mathrm{SO}_{4}{ }^{2-}$ reduction. $\delta^{34} \mathrm{~S}$ and $\delta^{18} \mathrm{O}$ values can be used in conjunction with $\mathrm{SO}_{4}{ }^{2-}$ and $\mathrm{Cl}^{-}$concentrations and ratios to help distinguish specific groundwater sources when there is a wide range of $\delta^{34} \mathrm{~S}$ values. (Dogramaci et al., 2001; Houhou et al., 2010)

\section{2 - FORMAT OF THESIS}

Chapter 1 contains the background information, literature review, and information regarding the design of the study and research presented here. Chapter 2 of this thesis is in manuscript format for potential submission to a scientific journal. 
Abstract

Water from fifty streams sampled at baseflow in the Monongahela River basin of West Virginia were analyzed for selected major and minor geochemistry, as well as stable isotopes of $\delta^{2} \mathrm{H}_{\mathrm{H} 2 \mathrm{O}}$, $\delta^{18} \mathrm{O}_{\mathrm{H} 2 \mathrm{O}}, \delta^{13} \mathrm{C}_{\mathrm{DIC}}, \delta^{18} \mathrm{O}_{\mathrm{SO} 4}$ and $\delta^{34} \mathrm{~S}_{\mathrm{SO} 4}$. The geochemical and isotopic characteristics of the 50 water samples collected show no clustering based on Marcellus Shale production category, which is used specifically for this study to quantify the amount of Marcellus production in a HUC-12 sub-watershed. The area with the greatest density of Marcellus Shale development has also undergone extensive coal mining. Hence geochemical characteristics were used to decouple the effects of coal mining from new shale gas development in the area. Extremely high concentrations of total dissolved solids (TDS) are characteristic of produced water from Marcellus Shale production. All of our samples have TDS concentrations less than $1000 \mathrm{mg} / \mathrm{L}$, with a direct correlation between TDS and dissolved sulfate concentration. Elevated dissolved sulfate concentrations in some samples are thought to be the result of upstream coal mine drainage. Values of stable isotopes of $\delta^{2} \mathrm{H}_{\mathrm{H} 2 \mathrm{O}}, \delta^{18} \mathrm{O}_{\mathrm{H} 2 \mathrm{O}}$, and $\delta^{13} \mathrm{C}_{\text {DIC }}$ in our samples show no enrichment in those isotopes, which is common in produced waters of Marcellus Shale production. The surface waters sampled show no geochemical or isotopic signatures consistent with impacts associated with produced waters from Marcellus Shale production.

\section{1 - INTRODUCTION}

Shale gas development in the Monongahela River basin in West Virginia has been intensifying since approximately 2007. The combination of multistage hydraulic fracture stimulation and directional drilling allows for extraction of hydrocarbon resources from low-permeability shale formations, such as the Marcellus Shale. In the process of hydraulic fracturing, an average of five million gallons of fresh water, sand, and chemicals are injected under high pressure to create permeability in the shale source rock to release hydrocarbons. On average, fresh water 
constitutes $98 \%$ of the total volume of the fluid used in hydraulic fracturing (Gregory et al., 2011). After the hydraulic fracturing process is initiated, a mixture of hydrocarbons, fracturing fluids, and formation brines are produced at the wellhead, also known as "produced water". The amount of fracturing fluid that returns to the surface as a component of produced water varies, but is often less than half of the original injected volume over the lifetime of the well (Engelder, 2012). Formation brines with total dissolved solids (TDS) in cases exceeding 250,000 mg/L are also a major constituent of produced water. The main geochemical contributors to formation waters are high concentrations of $\mathrm{Na}, \mathrm{Cl}, \mathrm{Sr}, \mathrm{Br}, \mathrm{Ba}$, and $\mathrm{Ca}$ ions, as well as radionuclides (Soeder and Kappel, 2009; Kargbo et al., 2010; Finkel and Law, 2011; Rowan et al., 2011; Warner et al., 2012; Haluszczak et al., 2013; Olmstead et al., 2013). In the Monongahela River basin, the depth to the Marcellus Shale ranges between 4,000 to 8,500 feet below the surface, with several thousand feet of mixed permeability sedimentary rocks (sandstone, shale, siltstone, limestone, coal) separating it from shallow groundwater aquifers and surface waters (Bruner and Smosna, 2011). There is concern that improper produced water management such as leakage from produced water holding ponds, illegal disposal of produced water, transportation accidents, well casing failures, and migration of brines through fracture networks and abandoned oil and gas wells can cause contamination of fresh water resources in areas of rapidly expanding shale gas drilling (Chapman et al., 2013; Olmstead et al., 2013).

The goal of this study was to compare the geochemistry of surface waters in areas with differing degrees of Marcellus Shale development/production in the Monongahela River basin of West Virginia to assess if shale gas drilling is impacting the surface water quality of streams in the region. The study area has a long history of coal mining and conventional oil and gas development. Most previous research has focused on understanding the impact of coal mining on 
the geochemical signatures of surface waters and groundwater. (U.S. EPA, 2002; Demchak et al., 2004; Petty and Barker, 2004; Stiles et al., 2004; Skousen et al., 2006; Merovich et al., 2007). In this study, we attempt to resolve geochemical and stable isotopic signatures of coal mine drainage from shale gas drilling in water chemistry of streams in study area.

\section{2 - STUDY AREA}

The study area covers $>2,700 \mathrm{mi}^{2}$ in the Monongahela River basin in West Virginia (Figure 1). The Monongahela River basin is dominated by Devonian, Mississippian, Pennsylvanian, and Permian sedimentary rocks. Lithologies are predominantly interbedded layers of sandstone, shale, siltstone, limestone, and coal strata that are gently dipping, generally to the northwest and southeast. The region lies entirely within the Allegheny Plateau physiographic province, which consists of well-developed stream networks surrounded by gentle to steep slopes. The basin is dominated by mixed deciduous and conifer forest cover, with small amounts of pasture/grassland present in mainly low-lying areas (Merovich et al., 2007).

At the time of sampling, (September 2012), 252 wells had been drilled in the Marcellus Shale in the Monongahela River basin of West Virginia, with the largest number of wells on the western edges of the basin (WVGES, 2012). Prior to the recent development of the Marcellus Shale, the Monongahela River basin has had long history of surface and underground coal mining. The most extensively mined coal bed in the Monongahela River basin is the Pittsburgh coal, with several others like the Freeport, Kittaning, Sewickley, and many other coal beds also playing a commercially important role. Acid mine drainage (AMD) is a common problem in areas with surface and underground coal mining. AMD results from the oxidation of pyritic minerals, which leads to the addition of acidity, sulfate, and dissolved metals to surface and groundwater 
resources. Several active (addition of sodium hydroxide, ammonia, hydrated lime) and passive (wetlands, limestone drains) systems of AMD remediation are common in the Monongahela River basin, which primarily rely on the addition of alkalinity to increase $\mathrm{pH}$ and reduce metal concentrations of AMD (U.S. EPA, 2002). The basin also has long history of conventional oil and gas development, with more than 55,000 active wells and 13,000 abandoned wells (WV DEP, 2011; WVGES, 2013), which might serve as pathways for migration of deeper brines. Other anthropogenic inputs such as acid rain, sewage effluent, industrial effluent, agriculture, road salt, and illegal refuse disposal are all possible contributors that can also affect the surface water quality in the region.

\section{3 - METHODS}

For this study 50 streams were sampled in the Monongahela River basin of West Virginia. Sample collection was done in collaboration with the USGS West Virginia Water Science Center. Sample sites were chosen by analyzing all 118 12-digit hydrologic unit code (HUC-12) sub-watersheds in the Monongahela River basin for their most recently reported degree of Marcellus Shale production (Figure 1). HUC-12 sub-watersheds were chosen for this study because of their relatively small size. All HUC-12 sub-watersheds in this study range in area from 10.4 to $40.7 \mathrm{mi}^{2}$, with an average area of $22.6 \mathrm{mi}^{2}$. Production information for wells drilled in the Marcellus was used from the West Virginia Geologic and Economic Survey, with the most current information available through the end of 2011. Five categories were created to represent different conditions within each HUC-12 sub-watershed with respect to Marcellus shale development as a way to compare surface water geochemistry between differing amounts of production with respect to Marcellus Shale operations. The number of samples in each category was meant to be proportional to the total number of HUC-12's that are in each category. The five 
categories are high production, low production, near high production, near low production, and no production. High production is designated as a HUC-12 that contains Marcellus Shale development that produces greater than $1,000 \mathrm{MCF} / \mathrm{mi}^{2} /$ year. Low production is designated as a HUC-12 that contains Marcellus Shale development that produces less than 1,000 $\mathrm{MCF} / \mathrm{mi}^{2} /$ year. Near high production and near low production are designated as HUC-12's that are adjacent to high production and low production, respectively. HUC-12's that are designated as no production contain no Marcellus Shale development in or adjacent to it, but are possible locations for Marcellus Shale development because they are underlain by Marcellus Shale greater than 50 feet thick. Sample locations were only included if previous sampling had been done by the USGS. Streams with known severe impacts from AMD were not used.

Samples were collected at baseflow conditions (August - October of 2012) to ensure that the primary contribution to surface water flow was from groundwater discharge. The width and depth of each stream site was first measured, and then a width-integrated sample was collected in an open-mouth handheld bottle and placed in a churn carrier. The churn carrier was filled with approximately 8 liters of water collected at intervals across the width of the stream to ensure that the final volume of water was representative of all of the water in the stream. Field parameters (pH, specific conductance, Eh, temperature, total dissolved solids, dissolved oxygen, and turbidity) were measured with an YSI 6920 V2 Sonde at each sample collection interval across width of stream. Average field conditions of each stream were then calculated using the width collected field parameters. Field alkalinity was calculated at each sample site using a standard titration with nitric acid.

All water samples for isotopic and geochemical analysis were taken from the width-integrated sample in the churn carrier. Samples for $\delta^{2} \mathrm{H}_{\mathrm{H} 2 \mathrm{O}}$ and $\delta^{18} \mathrm{O}_{\mathrm{H} 2 \mathrm{O}}$ were filled in an $8 \mathrm{~mL}$ pre-rinsed 
glass-threaded vial with no headspace. Random duplicate samples were taken for quality control purposes. Samples for $\delta^{13} \mathrm{C}_{\text {DIC }}$ were filtered through Cameo $0.45 \mu \mathrm{m}$ nylon pre-filter into a 10 $\mathrm{mL}$ Wheaton serum vial with no headspace. To halt any metabolic activity 1-2 drops of benzalklonium chrloride $(17 \% \mathrm{w} / \mathrm{w})$ were added to the Wheaton vial. Samples for dissolved sulfate $\left(\delta^{34} \mathrm{~S}\right.$ and $\left.\delta^{18} \mathrm{O}\right)$ were collected in a $1 \mathrm{~L}$ pre-rinsed high density polyethene bottle with no headspace. Samples were then filtered in the laboratory using a vacuum pump through a $45 \mathrm{~mm}$ $0.4 \mu \mathrm{m}$ PCM filter. Filtered water samples were shipped to Isotech Laboratories for sulfur and oxygen isotope analysis of sulfate.

Stable isotopes of $\delta^{2} \mathrm{H}_{\mathrm{H} 2 \mathrm{O}}, \delta^{18} \mathrm{O}_{\mathrm{H} 2 \mathrm{O}}$ and $\delta^{13} \mathrm{C}_{\mathrm{DIC}}$ were analyzed with a Finnigan Delta Advantage continuous flow isotope ratio mass spectrometer (CF-IRMS). The reproducibility and accuracy was $<0.2 \%$ for $\delta^{18} \mathrm{O}_{\mathrm{H} 2 \mathrm{O}}$ and $\delta^{13} \mathrm{C}_{\mathrm{DIC}}$, and $<1 \%$ o for $\delta^{2} \mathrm{H}_{\mathrm{H} 2 \mathrm{O}}$. Isotopic values are reported in per mil (\%o) relative to V-SMOW (Standard Mean Oceanic Water, for both $\delta^{2} \mathrm{H}_{\mathrm{H} 2 \mathrm{O}}$ and $\delta^{18} \mathrm{O}_{\mathrm{H} 2 \mathrm{O}}$ ) and VPDB (Pee Dee Belemnite) for $\delta^{13} \mathrm{C}_{\text {DIC }}$. The $\delta^{18} \mathrm{O}_{\mathrm{SO} 4}$ and $\delta^{34} \mathrm{~S}_{\mathrm{SO} 4}$ analyses were done at ISOTECH laboratories using high temperature conversion elemental analyzer (TC-EA) and elemental analyzer (EA) online with isotope ratio mass spectrometer, respectively. The $\delta^{34} \mathrm{~S}_{\mathrm{SO} 4}$ and $\delta^{18} \mathrm{O}_{\mathrm{SO} 4}$ are reported versus V-CDT (Vienna Canyon Diablo Trilobite) and (V-SMOW) respectively. The measurement precision for both $\delta^{34} \mathrm{~S}_{\mathrm{SO} 4}$ and $\delta^{18} \mathrm{O}_{\mathrm{SO} 4}$ analysis is approximately $\pm 0.5 \%$.

Analysis of major and minor ions and trace elements was performed at the National Water Quality Laboratory of the USGS. Na, Ca, Mg, Sr, K, Fe, Mn, and Si were analyzed by inductively coupled plasma atomic emission spectroscopy (ICP-EAS). $\mathrm{SO}_{4}, \mathrm{Cl}$, and $\mathrm{Br}$ were analyzed by iron chromatography (IC). TDS was measured by residue on evaporation. Trace elements of $\mathrm{Al}$ and $\mathrm{Br}$ were analyzed by inductively coupled plasma mass spectroscopy (ICP- 
MS) or cICP-MS. The reproducibility and accuracy of measurements of $\mathrm{Mg}, \mathrm{K}, \mathrm{Ca}$, and Fe were $11 \%$, and $3 \%$ for $\mathrm{SO}_{4}$ and $\mathrm{Cl}$.

\section{4 - RESULTS}

Results of major and minor ion chemistry as well as stable isotopic results from surface water samples are in Table 1 and plotted according to the different Marcellus Shale production categories on a Piper diagram (Figure 4). The two dominant water facies present are $\mathrm{Ca}-\mathrm{HCO}_{3}$ $(n=26)$ and $\mathrm{Ca}_{-} \mathrm{SO}_{4}(\mathrm{n}=10)$. Water facies for all samples are summarized in Table 2. The remaining 12 samples are $\mathrm{Na}-\mathrm{HCO}_{3}(\mathrm{n}=3), \mathrm{Na}-\mathrm{SO}_{4}(\mathrm{n}=3), \mathrm{Ca}-\mathrm{Na}-\mathrm{HCO}_{3}(\mathrm{n}=2), \mathrm{Ca}-\mathrm{Na}-\mathrm{SO}_{4}$ $(\mathrm{n}=1), \mathrm{Ca}-\mathrm{HCO}_{3}-\mathrm{Cl}(\mathrm{n}=1)$ and $\mathrm{Ca}-\mathrm{HCO}_{3}-\mathrm{SO}_{4}(\mathrm{n}=2)$.

Two sample locations were omitted from analysis in this study. Both sites were located downstream of a known AMD treatment plant near Indian Creek, WV. These sample locations, located at Indian Creek near Osgood, WV and Indian Creek at Crown, WV, showed TDS concentrations $(3,300$ and $4380 \mathrm{mg} / \mathrm{L})$ and sulfate concentrations $(2040$ and $2640 \mathrm{mg} / \mathrm{L})$ that were more than 2 standard deviations from the average TDS $(250 \mathrm{mg} / \mathrm{L})$ for all other samples. While these locations have high TDS values relative to the rest of the samples, the dominant anion in these waters is sulfate, which is not consistent with produced waters from Marcellus Shale production.

Stable isotopes of $\delta^{18} \mathrm{O}_{\mathrm{H} 2 \mathrm{O}}$ and $\delta^{2} \mathrm{H}_{\mathrm{H} 2 \mathrm{O}}$ values for all samples range from -4.25 to $-9.46 \%$ o SMOW and from -24.40 to $-59.80 \%$ V-SMOW, respectively. The oxygen and hydrogen isotope data from samples collected from different production categories were plotted against the expected isotopic composition of local meteoric waters defined by the Local Meteoric Water line (LMWL), with no clustering being seen between the different production categories (Figure 6). 
The LMWL was calculated using the online isotopes in precipitation calculator (OIPC) at Waterisotopes.org (Bowen 2013).

Stable isotopes of carbon of dissolved inorganic carbon (DIC) were analyzed for all samples. The $\delta^{13} \mathrm{C}_{\text {DIC }}$ ranged from -5.87 to $-14.57 \%$ VPDB in all samples except 2 samples having values of (-24.05\% and $-24.61 \%$ VPDB). Figure 7 shows $\delta^{13} \mathrm{C}_{\text {DIC }}$ values for the five production categories. No clustering is seen between production category and $\delta^{13} \mathrm{C}_{\text {DIC }}$ values. Two sample sites had DIC concentrations that were too low for analysis to be completed.

Stable isotopes of $\delta^{34} \mathrm{~S}_{\mathrm{SO} 4}$ values range from -7.60 to $+13.40 \%$ VCDT, while $\delta^{18} \mathrm{O}_{\mathrm{SO} 4}$ values range from -6.40 to $+10.60 \%$ VSMOW. Three samples did not contain enough dissolved sulfate to allow for isotopic analysis. Figure 8 shows a scatter plot of $\delta^{18} \mathrm{O}_{\mathrm{SO} 4}$ versus $\delta^{34} \mathrm{~S}_{\mathrm{SO} 4}$ for surface water samples. There is a wide range in values of $\delta^{18} \mathrm{O}_{\mathrm{SO} 4}$ versus $\delta^{34} \mathrm{~S}_{\mathrm{SO} 4}$ with no correlation between the production categories.

\section{$2.5-$ DISCUSSION}

\subsection{1 - SURFACE WATER GEOCHEMISTRY}

Surface water geochemistry was analyzed in areas for differing degrees of Marcellus Shale development. All stream water samples were collected at baseflow conditions; when all contributions to stream flow were primarily from groundwater discharge. The two principal aquifers in the study area are shallow unconfined alluvium and confined/unconfined bedrock. Discharges from point and non-point sources can also contribute to stream flow in the study area, but specific discharges were not identified or sampled. 
Low $\mathrm{pH}(<4.5)$ indicates moderate to severe AMD contamination on surface waters (Cravotta, 2008). The $\mathrm{pH}$ of all samples range from neutral to slightly alkaline (7.0 to 8.7),except 2 samples (pH 4.8 and 5.4) at Roaring Creek near Norton, WV and Sandy Creek near Evansville, WV. These 2 samples also have slightly elevated sulfate concentrations (112 mg/L an $144 \mathrm{mg} / \mathrm{L})$, low $\mathrm{HCO}_{3}$ concentrations $(0.40 \mathrm{mg} / \mathrm{L}$ and $8.30 \mathrm{mg} / \mathrm{L})$, elevated $\mathrm{Al}$ concentrations $(0.10 \mathrm{mg} / \mathrm{L}$ and $4.42 \mathrm{mg} / \mathrm{L})$, elevated total Fe concentrations $(0.03 \mathrm{mg} / \mathrm{L}$ and $1.04 \mathrm{mg} / \mathrm{L})$, and elevated $\mathrm{Mn}$ concentrations $(0.35 \mathrm{mg} / \mathrm{L}$ and $0.40 \mathrm{mg} / \mathrm{L})$, relative to all other samples in this study. The geochemical characteristics suggest waters receiving inputs from AMD (Sams III and Beer, 2000; Skousen et al., 2006; Merovich et al., 2007; Cravotta, 2008).

Elevated TDS concentrations in surface waters can indicate contamination from a variety of sources. Produced waters associated with Marcellus shale operations have very high concentrations of TDS $(>7,500 \mathrm{mg} / \mathrm{L})$ and high $\mathrm{Na}, \mathrm{Ca}, \mathrm{Cl}, \mathrm{Sr}$, and Ba concentrations. This unique geochemical composition can be used to distinguish them from fresh surface waters and shallow groundwaters (Chapman et al., 2012; Haluszczak et al., 2013; Olmstead et al., 2013). Salinity in produced water from Marcellus Shale operations is thought to be derived from the deep brines in the Marcellus or overlying strata (Haluszczak et al., 2013). The "high production" and "low production" HUC-12 samples show the highest average concentrations of TDS (445 $\mathrm{mg} / \mathrm{L}$ and $378 \mathrm{mg} / \mathrm{L}$, respectively). The "no production" category HUC-12 samples show the lowest average concentrations of TDS (77 mg/L). "Near high production" and "near low production" HUC-12's have average concentrations of TDS that are in between the high/low production HUC-12's and the no production HUC-12's (265 mg/L and $149 \mathrm{mg} / \mathrm{L}$, respectively). The geographic distribution of production categories is not uniform across the study area, with the western region (west of the Tygart Valley River and west of the Monongahela River) 
containing 11 of 12 of the "high production" HUC-12's, 8 of 12 of the "near high production" HUC-12's, and 3 of 5 of the "low production" HUC-12's. Of all "high production" category samples, $33 \%$ show higher TDS ( $>500 \mathrm{mg} / \mathrm{L}$ ) compared to $60 \%$ of samples in waters in the "low production" category. The samples with the highest concentrations of TDS ( $>500 \mathrm{mg} / \mathrm{L})$ all consist of $\mathrm{SO}_{4}$ anion-type waters with $\mathrm{SO}_{4}$ concentrations $>250 \mathrm{mg} / \mathrm{L}$ (Figure 5) There is also an observed bimodal distribution in the plot of TDS versus $\mathrm{SO}_{4}$ concentrations. This bimodal distribution in the samples is likely due to proximity to point and non-point discharge sources of coal mine drainage .

While produced water from Marcellus Shale operations show high TDS values $(7500 \mathrm{mg} / \mathrm{L}$ to $>250,000 \mathrm{mg} / \mathrm{L})$, they show low concentrations of dissolved sulfate $(<5 \mathrm{mg} / \mathrm{L}$ to $100 \mathrm{mg} / \mathrm{L})$ (Haluszczak et al., 2013). On other hand, high $\mathrm{SO}_{4}$ concentrations in surface waters of this region can be attributed to oxidation of sulfide in the pyrite-bearing bituminous coal and associated sedimentary rocks in the region (Sams III and Beer, 2000 ; Merovich et al., 2007). Coal mining (both underground and surface) is widespread throughout the Monongahela River basin. Elevated TDS could be indicative of surface waters impacted by acid mine drainage rather than produced waters associated with Marcellus Shale development. Waters that are severely impacted from $\mathrm{AMD}$ tend to have not only elevated $\mathrm{SO}_{4}$ concentrations, but elevated concentrations of $\mathrm{Fe}, \mathrm{Al}$, and $\mathrm{Mn}$ (Cravotta, 2008). While we see elevated concentrations of dissolved sulfate for a number of samples, we do not see corresponding elevated concentrations of $\mathrm{Fe}, \mathrm{Al}$, and $\mathrm{Mg}$. We hypothesize these geochemical characteristics possibly indicate that these waters are receiving small inputs from AMD sources and are being diluted with inputs from neutral to slightly alkaline water sources not affected by AMD (Cravotta et al., 2013). Additionally, because all but two samples show $\mathrm{pH}$ levels of 7 and above, the metals $\mathrm{Fe}, \mathrm{Al}$, and 
Mn will precipitate out of solution, normally as hydroxide-form minerals (Drever, 1997).

Flooded underground coal mines above and below drainage which produce AMD are prevalent throughout the Monongahela River basin (Donovan and Leavitt, 2004). Abandoned surface coal mines are also widespread throughout the basin, and can contribute AMD through point-source discharges or diffuse non-point contributions to streams and shallow groundwater (Petty and Barker, 2004). Migration of AMD-affected groundwater can also possibly migrate into shallow subsurface through the abandoned oil and gas wells in West Virginia (WV DEP 2011; Chapman et al., 2013). Therefore it appears that the source of high TDS in the samples are $\mathrm{SO}_{4}$ type waters associated with mine water discharges, rather than produced water associated with shale gas drilling in the region.

Five samples had relatively high $\mathrm{Cl}$ concentrations ( $>40 \mathrm{mg} / \mathrm{L}$ ) compared to the rest of the samples. Of the five samples with elevated $\mathrm{Cl}$ concentrations, one is in the "high production" category, three are in the "near high production" category, and one is in the "low production" category. These high concentrations relative to the rest of the samples may indicate additional sources that contribute to salinity of these waters. Dual plots of $\mathrm{Cl}(\mathrm{mg} / \mathrm{L})$ versus $\mathrm{Cl} / \mathrm{Br}$ molar ratios can be used to better understand the source of the salinity in waters. The $\mathrm{Cl}$ values plotted versus the $\mathrm{Cl} / \mathrm{Br}$ molar ratios for our samples show two prominent trends (Figure 9). The first trend is of an increase in $\mathrm{Cl}$ concentrations accompanied by an increase in the $\mathrm{Cl} / \mathrm{Br}$ ratio. This trend can be due to contributions from leaching of solid waste, road salt, or urban runoff (Cartwright et al., 2007; Alcalá and Custodio, 2008). Samples that show a Cl concentration increase with no corresponding increase in the $\mathrm{Cl} / \mathrm{Br}$ ratio could indicate contributions from $\mathrm{Br}$ based sources such as septic waste, pesticides, and livestock waste (Alcalá and Custodio, 2008). Low $\mathrm{Cl} / \mathrm{Br}$ ratios (100-300) can be indicative of oil-field brines (Vengosh and Pankratov, 1998; 
Alcalá and Custodio, 2008). However, these ratios are always accompanied by very high $\mathrm{Cl}$ and Br concentrations $(>10,000 \mathrm{mg} / \mathrm{L}$ and $>100 \mathrm{mg} / \mathrm{L}$, repsectively). While some of our samples show low $\mathrm{Cl} / \mathrm{Br}$ ratios (315 to 450 ), they show low $\mathrm{Cl}$ concentrations ( $<63.1 \mathrm{mg} / \mathrm{L}$ ) and low $\mathrm{Br}$ concentrations $(<0.26 \mathrm{mg} / \mathrm{L})$ relative to known values of $\mathrm{Cl}$ and $\mathrm{Br}$ for produced waters from Marcellus Shale operations (>10,000 mg/L). Hence the multiple geochemical characteristics indicate that water quality in several sampling locations is impacted by mine drainage and other urban pollution sources and not produced water associated with Marcellus Shale development.

\subsection{2 - OXYGEN AND HYDROGEN ISOTOPES}

Oxygen and hydrogen form the water molecule itself, making these isotopic proxies good natural tracers for tracking the sources of water. It is expected that the $\delta^{18} \mathrm{O}_{\mathrm{H} 2 \mathrm{O}}, \delta^{2} \mathrm{H}_{\mathrm{H} 2 \mathrm{O}}$ values of surface and shallow groundwater aquifers which are primarily recharged by isotopically lighter snowmelt and precipitation of recent times will follow the well-defined relationship between $\delta^{18} \mathrm{O}_{\mathrm{H} 2 \mathrm{O}}$ and $\delta^{2} \mathrm{H}_{\mathrm{H} 2 \mathrm{O}}$ values of local water defined by the local meteoric water line (LMWL), a variant of the global meteoric water line (GMWL) (Craig 1961). On the other hand, formation brines (which can form a significant portion of produced water) will have very different $\delta^{18} \mathrm{O}_{\mathrm{H} 2 \mathrm{O}}$, and $\delta \mathrm{D}_{\mathrm{H} 2 \mathrm{O}}$ as they originate from local meteoric water recharged thousands to millions of years ago or marine connate water deposited with shales and siltstones. Further, the $\delta^{18} \mathrm{O}_{\mathrm{H} 2 \mathrm{O}}$ and $\delta^{2} \mathrm{H}_{\mathrm{H} 2 \mathrm{O}}$ isotopic composition of formation waters will also be modified by isotopic exchange between waters and minerals/fluids, evaporation and condensation (Kharaka and Thordsen, 1992; Clark and Fritz, 1997; Kendall and Coplen, 2001; Blasch and Bryson, 2007) . Therefore, $\delta^{18} \mathrm{O}_{\mathrm{H} 2 \mathrm{O}}$ and $\delta^{2} \mathrm{H}_{\mathrm{H} 2 \mathrm{O}}$ signatures of different water sources i.e. produced waters, shallow versus deep groundwaters aquifers, and surface waters are likely to be very different from one another and can potentially help to distinguish the different sources. 
No major deviations from the LMWL have been observed from the samples, indicating that meteoric water and shallow groundwater recharged during modern times is a major component in these streams. The isotopic variations and differences in slope and intercept of different water samples likely represent slight variations in sources and time of recharge. Water samples collected from streams at highest elevations, 1,335 to 2,854 feet above sea level (ASL), are located on the eastern and southern edges of the study area show most depleted values of $\delta^{18} \mathrm{O}_{\mathrm{H} 2 \mathrm{O}}$ and $\delta^{2} \mathrm{H}_{\mathrm{H} 2 \mathrm{O}}$ due to the elevation effect (Dansgaard, 1964). None of the water samples show enriched $\delta^{18} \mathrm{O}_{\mathrm{H} 2 \mathrm{O}}$ and $\delta^{2} \mathrm{H}_{\mathrm{H} 2 \mathrm{O}}$ composition as seen in produced waters associated with Marcellus shale development (Dresel and Rose, 2010; Warner et al., 2012, Sharma et al., 2013a). Additionally, none of the water samples show preferential enrichment of $\delta^{18} \mathrm{O}_{\mathrm{H} 2 \mathrm{O}}$, over $\delta^{2} \mathrm{H}_{\mathrm{H} 2 \mathrm{O}}$ leading to a more horizontal shift to the right of the GMWL as seen in the brines of the area (Warner et al., 2012; Sharma et al., 2013a). Therefore, it appears that none of the streams are receiving significant contributions from saline brines or formation waters associated with Shale Gas development, natural migration along faults in the area, or surface disposal close to the time of sampling. The observed control on $\delta^{18} \mathrm{O}_{\mathrm{H} 2 \mathrm{O}}$ and $\delta^{2} \mathrm{H}_{\mathrm{H} 2 \mathrm{O}}$ variations are likely due to differences in local soil water, groundwater residence times, seasonality of recharge, and elevation effects.

\subsection{3 - CARBON ISOTOPES OF DISSOLVED INORGANIC CARBON}

The carbon isotope signature of dissolved inorganic carbon (DIC) is another tracer that can be used to distinguish different water sources as carbon originating from different sources have distinct isotopic signatures. DIC has also shown to be an important natural tracer for tracking sources of anthropogenic impacts on surface and groundwaters. (Brunet et al., 2005; Doctor et al, 2008; Fonyuy and Atekwana, 2008; Sharma and Frost, 2008; Sharma et al., 2013b) 
The main sources of DIC in surface waters are carbon originating from the decay of organic matter, carbonate dissolution, and invasion of atmospheric $\mathrm{CO}_{2}(\mathrm{~g})$. DIC is composed of three main species of carbon: $\mathrm{HCO}_{3}{ }^{-}, \mathrm{CO}_{3}{ }^{2-}$, and $\mathrm{H}_{2} \mathrm{CO}_{3}$ which is primarily in the form $\mathrm{CO}_{2}(\mathrm{aq})$. In neutral $\mathrm{pH}$ waters, the main DIC species is in the form of the bicarbonate $\left(\mathrm{HCO}_{3}{ }^{-}\right)$ion. The relative contribution of carbon from different end-members and carbon speciation ultimately controls the overall $\delta^{13} \mathrm{C}_{\mathrm{DIC}}$ composition of the water. The range of $\delta^{13} \mathrm{C}_{\mathrm{DIC}}$ in most natural waters receiving almost equal contributions from decaying organic matter and soil carbonate dissolution and leads to ranges between -11 to $-16 \%$ VPDB (Clark and Fritz, 1997). The $\delta^{13} \mathrm{C}_{\mathrm{DIC}}$ in the majority of water samples ranges from -5.87 to $-14.57 \%$ VPDB with exception of two samples with $\delta^{13} \mathrm{C}_{\mathrm{DIC}}$ values of $-24.05 \%$ and $-24.61 \%$ o VPDB. These two samples were collected from the "high production" and "near low production" categories in study area. The $\delta^{13} \mathrm{C}_{\mathrm{DIC}}$ values of produced water from Marcellus Shale wells was found to be highly enriched (average $+21 \%$ o VPDB) due to late stage biogenic methanogenesis (Sharma et al., 2013b). However, none of our water samples had positive $\delta^{13} \mathrm{C}_{\mathrm{DIC}}$ signatures similar to produced water from Marcellus Shale operations. The low $\delta^{13} \mathrm{C}_{\mathrm{DIC}}$ value ( $\sim-24 \%$ ) in two samples is attributed to oxidation of isotopically depleted sources like modern soil organic matter decay or coals/shales in the region, which range from (-21.6 to $-25.4 \%$ VPDB) (Sharma et al., 2013b). Out of the remaining samples, $58 \%$ have $\delta^{13} \mathrm{C}_{\mathrm{DIC}}$ values higher than $-11 \%$ o suggesting greater contribution from dissolution of isotopically enriched carbonate rocks. In areas where AMD is a common occurrence, oxidation of pyritic sulfides in coal beds can generate acidity which can result in enhanced dissolution of isotopically enriched carbonate (Sharma et al., 2013b). Degassing of isotopically depleted $\mathrm{CO}_{2}$ species from total DIC in standing or slow moving streams or invasion of isotopically enriched atmospheric $\mathrm{CO}_{2}$ in waters with low $\mathrm{P}^{\mathrm{CO} 2}$ can also result in slight 
enrichment in $\delta^{13} \mathrm{C}_{\text {DIC }}$ of waters (Atekwana and Krishnamurthy, 1998; Doctor et al., 2008;

Sharma et al., 2013b). This indicates that some of the enriched $\delta^{13} \mathrm{C}_{\text {DIC }}$ signatures seen in streams could be result of contribution from mine discharges or atmospheric exchange in very slow moving streams.

\subsection{4 - SULFUR AND OXYGEN ISOTOPES OF DISSOLVED SULFATE}

The stable isotopes of $\delta^{34} \mathrm{~S}_{\mathrm{SO} 4}$ and $\delta^{18} \mathrm{O}_{\mathrm{SO} 4}$ can be used to distinguish sources of dissolved sulfate in streams and the processes controlling the overall sulfate concentration. Because dissolved sulfate $\left(\mathrm{SO}_{4}\right)$ is ubiquitous in the streams sampled, stable isotopes of $\delta^{34} \mathrm{~S}_{\mathrm{SO} 4}$ and $\delta^{18} \mathrm{O}_{\mathrm{SO} 4}$ are well suited to better understand sulfate dynamics of surface waters in the study area. Stable isotopes of $\delta^{34} \mathrm{~S}_{\mathrm{SO} 4}$ and $\delta^{18} \mathrm{O}_{\mathrm{SO} 4}$ have been used in previous studies to understand AMD dynamics (Taylor et al.,1984; Gammons et al., 2010), atmospheric sulfur deposition (Mast et al., 2001), and groundwaters receiving input from sewage effluent (Bottrell et al., 2008).

A scatterplot of values of $\delta^{18} \mathrm{O}_{\mathrm{SO} 4}$ versus $\delta^{34} \mathrm{~S}_{\mathrm{SO} 4}$ shows no correlation between the Marcellus Shale production categories (Figure 8). It is assumed that the primary source of dissolved sulfate in the samples for this study is from the oxidation of pyritic minerals, due to known widespread occurrences of AMD across the study area from previously published work. The large variation in values of $\delta^{34} \mathrm{~S}_{\mathrm{SO} 4}$ could be due to the wide range in values for pyrite minerals found in many strata in the study area (Mulder et al., 2012). There is little to no fractionation of sulfur during the oxidation of sulfide, meaning $\delta^{34} \mathrm{~S}_{\mathrm{SO} 4}$ values will remain virtually the same as the material they were derived from. However, bacterial sulfate reduction occurring in anaerobic waters such as coal mines causes both $\delta^{34} \mathrm{~S}_{\mathrm{SO} 4}$ and $\delta^{18} \mathrm{O}_{\mathrm{SO} 4}$ enrichment. This is due to the preferential use of the lighter ${ }^{32} \mathrm{~S}$ isotope by sulfate-reducing bacteria. If we assume that pyrite oxidation is the main source of dissolved sulfate in these waters, we must also note that the $\delta^{34} \mathrm{~S}_{\mathrm{SO} 4}$ value of pyrite in 
general has a wide range, from -25 to $0 \%$ VCDT (Clark and Fritz, 1997). Specific bulk $\delta^{34} \mathrm{~S}_{\mathrm{SO} 4}$ values for pyrite, shales, and coals in the study area were not investigated as part of this research. However, a recent study (Sharma et al., 2013b) found that coals and shales of the Pittsburgh coal bed had $\delta^{34} \mathrm{~S}_{\mathrm{SO} 4}$ values ranging from $+0.6 \%$ to $+2.4 \%$ VCDT. Reducing conditions are unlikely for these surface waters; therefore, we can assume that bacterial sulfate reduction is not occurring in the streams sampled. However, contributions to stream flow from flooded underground mines or abandoned surface mines where anaerobic reducing conditions are possible, but are not known for the locations sampled. Because our samples show $\delta^{34} \mathrm{~S}_{\mathrm{SO}}$ values ranging from -7.60 to $+13.40 \%$ VCDT, it is not clear if samples with enriched values of $\delta^{34} \mathrm{~S}_{\mathrm{SO} 4}$ are so because of streams receiving input from dissolved sulfate that has been bacterially reduced, or the values for $\delta^{34} \mathrm{~S}_{\mathrm{SO} 4}$ from which the sulfate is derived have enriched values ( $>0 \%$ ). Stable isotope values of $\delta^{18} \mathrm{O}_{\mathrm{SO} 4}$ also show a wide range. The source of oxygen in dissolved sulfate is derived from both the oxygen molecule in water and also from atmospheric $\mathrm{O}_{2}(\mathrm{Gu}$ et al., 2008; Toran and Harris, 1989). The value of $\delta^{18} \mathrm{O}_{\mathrm{SO} 4}$ will depend largely upon the environment that the sulfide oxidation occurred in. For our samples we see $85 \%$ of the samples that have $\delta^{18} \mathrm{O}_{\mathrm{SO} 4}$ values greater than $0 \%$, indicating that these samples are receiving ${ }^{18} \mathrm{O}$ from atmospheric $\mathrm{O}_{2}$, which has a more enriched value relative to surface waters in the study area. Because of the large range in $\delta^{34} \mathrm{~S}_{\mathrm{SO} 4}$ and $\delta^{18} \mathrm{O}_{\mathrm{SO} 4}$ values that we see in the samples, we hypothesize there are a multiple processes at play such as sulfate reduction, atmospheric input, and a wide range of values for pyrite. 


\section{6 - CONCLUSIONS}

None of the geochemical or isotopic parameters show any clustering by the "Marcellus Production Category" that was created specifically for this study area. Many streams were found to contain elevated levels of TDS, dissolved sulfate, sodium, and calcium, which we associate primarily with acid mine drainage with possible secondary inputs from sewage effluent and agricultural production. A bimodal distribution was observed in the plot of TDS versus $\mathrm{SO}_{4}$ concentrations, which suggests that samples with higher concentrations of TDS and $\mathrm{SO}_{4}$ may be in closer proximity to point and non-point discharges of coal mine drainage. Stable isotope signatures of $\delta^{18} \mathrm{O}_{\mathrm{H} 2 \mathrm{O}}$ and $\delta^{2} \mathrm{H}_{\mathrm{H} 2 \mathrm{O}}$ indicate that primary source of recharge is modern precipitation or aquifers recharged by recent water indicating these surface waters are not receiving any significant contribution from brines from deeper formations either via natural faults fractures or pathways created by new shale gas drilling in the region. . The $\delta^{13} \mathrm{C}_{\mathrm{DIC}}$, $\delta^{34} \mathrm{~S}_{\mathrm{SO} 4}$, and $\delta^{18} \mathrm{O}_{\mathrm{SO} 4}$ signatures of waters also do not show any clustering with different production categories and are similar to values reported for coal mine discharges in the Appalachians. While our preliminary geochemical and isotopic data indicates that there is no evidence of impact from accelerating shale gas development on surface waters in the basin, this sampling represents a "one-time snapshot" of water quality in the streams under low-flow conditions. To better assess any impact of Marcellus Shale gas development on water quality of streams sampling near potential discharge sources and seasonal/monthly/continuous monitoring of water quality is required. However, our study provides water quality data for 50 surface water streams from areas under different stages of Marcellus Shale gas production and demonstrates how geochemical and stable isotopic composition of waters can be used to distinguish sources of salinity. 


\section{Acknowledgements}

This work was supported by a 104b grant to Dr. Shikha Sharma from the USGS. Special thanks to Jeremy White, Doug Chamber, Katherine Paybins, Terrance Messinger, and Hugh Bevans of the USGS-WV Water Science Center. Additional thanks to students and staff of the WVU Stable Isotope Facility. 


\section{$3.0-$ CONCLUSIONS}

Fifty surface water sites were analyzed for routine geochemistry as well as stable isotopic geochemistry in the Monongahela River basin of West Virginia for this study. The "Marcellus Shale Production Category" created for this study, intended to differentiate samples based on the amount of Marcellus Shale production in a HUC-12 watershed, showed no clustering of geochemical or isotopic parameters based on the categorization used for this study. No samples were shown to have characteristic geochemical signatures (extremely high TDS, chloride, sodium, and calcium) or stable isotopic compositions (significant shift to the right from the LMWL, enriched $\delta^{13} \mathrm{C}_{\mathrm{DIC}}$ ) that are known from produced water associated with Marcellus Shale production. If any inputs in to the surface water systems sampled for this study occurred, there were of such insignificant amounts that no clear indication could be gleaned from the geochemical or isotopic parameters used for this study. The largest input in to surface water systems that were observed were from geochemical parameters associated with acid mine drainage waters. Several streams had elevated TDS concentrations, with a corresponding elevated concentration in dissolved sulfate, sodium, and calcium. A bimodal distribution was observed in the plot of TDS versus $\mathrm{SO}_{4}$ concentrations, which suggests that samples with higher concentrations of TDS and $\mathrm{SO}_{4}$ may be in closer proximity to point and non-point discharges of coal mine drainage. With the long history of coal mining through this watershed, these results are not unexpected. Some contributions from agricultural and sewage drainage were seen in samples, with mixing occurring between these inputs and natural waters. Stable isotopes of $\delta^{18} \mathrm{O}_{\mathrm{H} 2 \mathrm{O}}$ and $\delta^{2} \mathrm{H}_{\mathrm{H} 2 \mathrm{O}}$ indicate that primary source of recharge is modern precipitation or aquifers recharged by recent water indicating these surface waters are not receiving any significant contribution from brines from deeper formations either via natural faults fractures or pathways created by new 
shale gas drilling in the region. The $\delta^{13} \mathrm{C}_{\mathrm{DIC}}, \delta^{34} \mathrm{~S}_{\mathrm{SO} 4}$, and $\delta^{18} \mathrm{O}_{\mathrm{SO} 4} \mathrm{signatures}$ of waters also do not show any clustering with different production categories and are similar to values reported for coal mine discharges in the Appalachians.

The samples collected for this study show no indication of contamination of surface water in the Monongahela River Basin of West Virginia of geochemical parameters associated with produced water from Marcellus Shale production. However, surface water sites were only sampled once, at baseflow conditions, and only show a "one-time snapshot" of the study sites. While the data presented in this study can provide a baseline for future studies, the conclusions reached here are based on a one-time sampling protocol. As the development of the Marcellus Shale continues to expand in the Monongahela River Basin of West Virginia (and elsewhere), further studies of geochemical and isotopic parameters, such as the one presented here, should be done on surface waters and groundwaters in this area. Future studies should focus on increased frequency sampling (monthly, weekly, or continuous), and should include isotopic composition of precipitation that falls in the watershed. 


\section{0 - REFERENCES}

Energy Information Administration, (2012). AEO2012 Early Release Overview (Vol. 2012, pp. $1-13)$.

Alcalá, F. J., \& Custodio, E. (2008). Using the $\mathrm{Cl} / \mathrm{Br}$ ratio as a tracer to identify the origin of salinity in aquifers in Spain and Portugal. Journal of Hydrology, 359(1-2), 189-207.

Arthur, J. D., Bohm, B., Coughlin, B. J., Layne, M., \& Consulting, A. L. L. (2009). SPE 121038 Evaluating Implications of Hydraulic Fracturing in Shale Gas Reservoirs, (March), 23-25.

Arthur, J. D., Uretsky, M., Wilson, P., \& Consulting, A. L. L. (2011). Water Resources and Use for Hydraulic Fracturing in the Marcellus Shale Region (pp. 1-22).

Atekwana, E. A., \& Krishnamurthy, R. V. (1998). Seasonal variations of dissolved inorganic carbon and 13C of surface waters: application of a modified gas evolution technique. Journal of Hydrology, 205, 265-278.

Atekwana, E., \& Fonyuy, E. W. (2009). Dissolved inorganic carbon concentrations and stable carbon isotope ratios in streams polluted by variable amounts of acid mine drainage. Journal of Hydrology, 372(1-4), 136-148.

Banks, D., Younger, P. L., Egil, R. A., \& Sheila, R. I. (1997). Mine-water chemistry : the good, the bad and the ugly. Environmental Geology, 32(October), 157-174.

Blasch, K. W., \& Bryson, J. R. (2007). Distinguishing sources of ground water recharge by using delta2H and delta180. Groundwater, 45(3), 294-308.

Bottrell, S., Tellam, J., Bartlett, R., \& Hughes, A. (2008). Isotopic composition of sulfate as a tracer of natural and anthropogenic influences on groundwater geochemistry in an urban sandstone aquifer, Birmingham, UK. Applied Geochemistry, 23(8), 2382-2394.

Brooks, B. W., Grover, J. P., \& Roelke, D. L. (2011). Prymnesium parvum: an emerging threat to inland waters. Environmental toxicology and chemistry / SETAC, 30(9), 1955-64.

Bruner, K., \& Smosna, R. (2011). A Comparative Study of the Mississippian Barnett Shale, Fort Worth Basin, and Devonian Marcellus Shale, Appalachian Basin (p. 106).

Brunet, F., Gaiero, D., Probst, J. L., Depetris, P. J., Gauthier Lafaye, F., \& Stille, P. (2005). $\delta 13$ $\mathrm{C}$ tracing of dissolved inorganic carbon sources in Patagonian rivers (Argentina). Hydrological Processes, 19(17), 3321-3344.

Cartwright, I., Hannam, K., \& Weaver, T. R. (2007). Constraining flow paths of saline groundwater at basin margins using hydrochemistry and environmental isotopes: Lake Cooper, Murray Basin, Australia. Australian Journal of Earth Sciences, 54(8), 1103-1122. 
Chapman, E. C., Capo, R. C., Stewart, B. W., Hedin, R. S., Weaver, T. J., \& Edenborn, H. M. (2013). Strontium isotope quantification of siderite, brine and acid mine drainage contributions to abandoned gas well discharges in the Appalachian Plateau. Applied Geochemistry, 31, 109-118.

Chapman, E. C., Capo, R. C., Stewart, B. W., Kirby, C. S., Hammack, R. W., Schroeder, K. T., \& Edenborn, H. M. (2012). Geochemical and Strontium Isotope Characterization of Produced Waters from Marcellus Shale Natural Gas Extraction. Environmental Science \& Technology, 46, 3545-3553.

Chunfang, C. A. I., Jiyang, W., \& Fangang, Z. (2001). Origin , migration and mixing of oilfield brines : Stable isotopic evidence from Kuqa Foreland Basin. Science in China (Series E), 44(August), 175-180.

Clark, I. D., \& Fritz, P. (1997). Environmental Isotopes in Hydrogeology (p. 328). CRC Press/Lewis Publishers.

Connolly, C. A., Walter, L. M., Baadsgaard, H., \& Longstaffe, F. J. (1990). Origin and evolution of formation waters, Alberta Basin, Western Canada Sedimentary Basin. II. Isotope systematics and water mixing. Applied Geochemistry, 5, 397-413.

Craig, H. (1961). Isotopic Variations in Meteoric Water. Science, 133(3465), 1702-1703.

Cravotta, C. A., (2008). Dissolved metals and associated constituents in abandoned coal-mine discharges, Pennsylvania, USA. Part 1: Constituent quantities and correlations. Applied Geochemistry, 23(2), 166-202.

Cravotta, C. A., Goode, D. J., Bartles, M. D., Risser, D. W., \& Galeone, D. G. (2013). Surfacewater and groundwater interactions in an extensively mined watershed, upper Schuylkill River, Pennsylvania, USA. Hydrological Processes, In Press.

Dansgaard, W. (1964). Stable Isotopes in Precipitation. Tellus, 16(4), 436-468.

Demchak, J., Skousen, J., \& McDonald, L. M. (2004). Longevity of acid discharges from underground mines located above the regional water table. Journal of Environmental Quality, 33(2), 656-68.

Department of Economic and Social Affairs Population Division, U. N. (2011). World Population Prospects The 2010 Revision (p. 142). New York, NY.

Department of Environmental Protection, W. V. (2011). West Virginia State of the Environment Report (p. 30).

Diefendorf, A. F., \& Patterson, W. P. (2005). Survey of stable isotope values in Irish surface waters. Journal of Paleolimnology, 34(2), 257-269. 
Doctor, D. H., Kendall, C., Sebestyen, S. D., Shanley, J. B., Ohte, N., \& Boyer, E. W. (2008). Carbon isotope fractionation of dissolved inorganic carbon ( DIC ) due to outgassing of carbon dioxide from a headwater stream. Hydrological Processes, 2423, 2410-2423.

Dogramaci, S. S., Herczeg, A. L., Schi, S. L., \& Bone, Y. (2001). Controls on d 34 S and d 18 O of dissolved sulfate in aquifers of the Murray Basin, Australia and their use as indicators of flow processes. Applied Geochemistry, 16, 475-488.

Donovan, J. J., \& Leavitt, B. R. (2004). The future of mine-water discharges from underground coal mines of the Pittsburgh Coal Basin. In National Meeting of the American Society of Mining and Reclamation (pp. 518-528).

Dresel, E., \& Rose, A. W. (2010). Chemistry and Origin of Oil and Gas Brines in Western Pennsylvania. Pennsylvania Geological Survey, 4th ser.,Open-File Report OFOG 10-01.0, (pp. 1-56).

Drever, J. I. (1997). The geochemistry of natural waters: surface and groundwater environments (p. 436). Prentice Hall.

Dutton, A., Wilkinson, B. H., Welker, J. M., Bowen, G. J., \& Lohmann, K. C. (2005). Spatial distribution and seasonal variation in $18 \mathrm{O} / 16 \mathrm{O}$ of modern precipitation and river water across the conterminous USA. Hydrological Processes, 19(20), 4121-4146.

Engelder, T. (2012). Capillary tension and imbibition sequester frack fluid in Marcellus gas shale. Proceedings of the National Academy of Sciences of the United States of America, 109(52), E3625; author reply E3626.

Finkel, M. L., \& Law, A. (2011). The rush to drill for natural gas: a public health cautionary tale. American Journal of Public Health, 101(5), 784-5.

Fonyuy, E. W., \& Atekwana, E. A. (2008). Effects of acid mine drainage on dissolved inorganic carbon and stable carbon isotopes in receiving streams. Applied Geochemistry, 23(4), 743764.

Freeman, J. T. (2007). The use of bromide and chloride mass ratios to differentiate saltdissolution and formation brines in shallow groundwaters of the Western Canadian Sedimentary Basin. Hydrogeology Journal, 15(7), 1377-1385.

Fricke, H. C., \& O’Neil, J. R. (1999). The correlation between $18 \mathrm{O}=16 \mathrm{O}$ ratios of meteoric water and surface temperature : its use in investigating terrestrial climate change over geologic time. Earth and Planetary Science Letter, 170, 181-196.

Gammons, C. H., Duaime, T. E., Parker, S. R., Poulson, S. R., \& Kennelly, P. (2010). Geochemistry and stable isotope investigation of acid mine drainage associated with abandoned coal mines in central Montana, USA. Chemical Geology, 269(1-2), 100-112. 
Gat, J. (1996). Oxygen and hydrogen isotopes in the hydrologic cycle. Annual Review of Earth and Planetary Sciences, 24, 225-262.

Gibson, J. J., Edwards, T. W. D., Birks, S. J., St Amour, N. a., Buhay, W. M., McEachern, P., ... Peters, D. L. (2005). Progress in isotope tracer hydrology in Canada. Hydrological Processes, 19(1), 303-327.

Gregory, K. B., Vidic, R. D., \& Dzombak, D. a. (2011). Water Management Challenges Associated with the Production of Shale Gas by Hydraulic Fracturing. Elements, 7(3), 181186.

Gu, A., Gray, F., Eastoe, C. J., Norman, L. M., Duarte, O., \& Long, A. (2008). Tracing ground water input to base flow using sulfate (S, O) isotopes. Groundwater, 46(3), 502-9.

Haluszczak, L. O., Rose, A. W., \& Kump, L. R. (2013). Geochemical evaluation of flowback brine from Marcellus gas wells in Pennsylvania, USA. Applied Geochemistry, 28, 55-61.

Hillaire-marcel, C., Helie, J.-F., \& Rondeau, B. (2002). Seasonal changes in the sources and f luxes of dissolved inorganic carbon through the St . Lawrence River - isotopic and chemical constraint. Chemical Geology, 186, 117-138.

Houhou, J., Lartiges, B. S., France-Lanord, C., Guilmette, C., Poix, S., \& Mustin, C. (2010). Isotopic tracing of clear water sources in an urban sewer: A combined water and dissolved sulfate stable isotope approach. Water Research, 44(1), 256-66.

Kargbo, D. M., Wilhelm, R. G., \& Campbell, D. J. (2010). Natural gas plays in the Marcellus Shale: challenges and potential opportunities. Environmental Science \& Technology, 44(15), 5679-84.

Kendall, C., \& Coplen, T. B. (2001). Distribution of oxygen-18 and deuterium in river waters across the United States. Hydrological Processes, 15, 1363-1393.

Kharaka, Y. K., \& Thordsen, J. J. (1992). Stable isotope geochemistry and origin of waters in sedimentary basins. Isotopic Signatures and Sedimentary Records. Lecture Notes in Earth Sciences, 42, 411-466).

Lambs, L., Balakrishna, K., Brunet, F., \& Probst, J. L. (2005). Oxygen and hydrogen isotopic composition of major Indian rivers: a first global assessment. Hydrological Processes, 19(17), 3345-3355.

Lu, X., Salovaara, J., \& McElroy, M. B. (2012). Implications of the recent reductions in natural gas prices for emissions of $\mathrm{CO} 2$ from the US power sector. Environmental Science \& Technology, 46(5), 3014-21. 
Maekawa, T., Igari, S.-I., \& Kaneko, N. (2006). Chemical and isotopic compositions of brines from dissolved-in-water type natural gas fields in Chiba , Japan. Geochemical Journal, 40, $475-484$.

Mast, M. A., Turk, J. T., Ingersoll, G. P., Clow, D. W., \& Kester, C. L. (2001). Use of stable sulfur isotopes to identify sources of sulfate in Rocky Mountain snowpacks. Atmospheric Environment, 35(19), 3303-3313.

McLaughlin, J. F., Frost, C. D., \& Sharma, S. (2011). Geochemical analysis of Atlantic Rim water, Carbon County, Wyoming: New applications for characterizing coalbed natural gas reservoirs. AAPG Bulletin, 95(2), 191-217.

Merovich, G. T., Stiles, J. M., Petty, J. T., Ziemkiewicz, P. F., \& Fulton, J. B. (2007). Water chemistry-based classification of streams and implications for restoring mined Appalachian watersheds. Environmental Toxicology and Chemistry / SETAC, 26(7), 1361-9.

Mulder, M. L., (2012). Ambient Geochemical and Isotopic Variations in Groundwaters Across an Area of Accelerating Shale Gas Development. Unpulished M.S.Thesis, West Virginia University, (p. 101).

Olmstead, S. M., Muehlenbachs, L. A, Shih, J.-S., Chu, Z., \& Krupnick, A. J. (2013). Shale gas development impacts on surface water quality in Pennsylvania. Proceedings of the National Academy of Sciences of the United States of America, 110(13) 4962-4967.

Osborn, S. G., Vengosh, A., Warner, N. R., \& Jackson, R. B. (2011). Methane contamination of drinking water accompanying gas-well drilling and hydraulic fracturing. Proceedings of the National Academy of Sciences of the United States of America, 108(20), 8172-6.

Petty, J. T., \& Barker, J. (2004). Water quality variability in tributaries of the Cheat River, a mined Appalachian watershed. In National Meeting of the American Society of Mining and Reclamation (pp. 1484-1504).

Renner, R. (2009). Salt-loving algae wipe out fish in Appalachian stream. Environmental science \& technology, 43(24), 9046-7.

Rowan, E. L., Engle, M. A., Kirby, C. S., \& Kraemer, T. F. (2011). Radium Content of Oil- and Gas-Field Produced Waters in the Northern Appalachian Basin (USA), USGS Scientific Investigations Report 2011-5135, (p. 38).

Rozanski, K., Araguas-Araguas, L., \& Gonfiantini, R. (1993). Isotopic Patterns in Modern Global Precipitation. Geophysical Monograph, 78, 1-36.

Rozanski, K., Froehlich, K., \& Mook, W. G. (2001). Environmental isotopes in the hydrological cycle Volume III. Atomic Energy (Vol. 111, p. 121). Paris. 
Rueedi, J., Cronin, a. a., Taylor, R. G., \& Morris, B. L. (2006). Tracing sources of carbon in urban groundwater using $\delta^{13} \mathrm{C}_{\mathrm{TDIC}}$ ratios. Environmental Geology, 52(3), 541-557.

Sams III, J. I., \& Beer, K. M. (2000a). Effects of Coal-Mine Drainage on Stream Water Quality in the Allegheny and Monongahela River Basins - Sulfate Transport and Trends, WaterResources Investigations Report 99-4208, USGS. (pp. 1-23).

Schulte, P., Geldern, R. Van, Freitag, H., Karim, A., Négrel, P., Petelet-giraud, E., ... Barth, J. A. C. (2011). Earth-Science Reviews Applications of stable water and carbon isotopes in watershed research: Weathering, carbon cycling, and water balances. Earth Science Reviews, 109(1-2), 20-31.

Seal, R. R. (2006). Sulfur Isotope Geochemistry of Sulfide Minerals. Reviews in Mineralogy and Geochemistry, 61(1), 633-677.

Seal, R. R., Alpers, C. N., \& Rye, R. O. (2000). Stable Isotope Systematics of Sulfate Minerals. Reviews in Mineralogy and Geochemistry, 40(1), 541-602.

Sharma, S, \& Frost, C. D. (2008). Tracing coalbed natural gas-coproduced water using stable isotopes of carbon. Groundwater, 46(2), 329-34.

Sharma, S., Mulder, M. L., Sack, A., Schroeder, K. T., \& Hammack, R. W. (2013a). Isotope approach to assess hydrologic connections during Marcellus Shale drilling. Groundwater.

Sharma, S., Sack, A., Adams, J. P., Vesper, D. J., Capo, R. C., Hartsock, A., \& Edenborn, H. M. (2013b). Isotopic evidence of enhanced carbonate dissolution at a coal mine drainage site in Allegheny County, Pennsylvania, USA. Applied Geochemistry, 29, 32-42.

Skousen, J., Mcdonald, L., Mack, B., \& Demchak, J. (2006). Water quality from above-drainage underground mines over a 35-year period. In International Conference on Acid Rock Drainage (pp. 2044-2054).

Soeder, B. D. J., \& Kappel, W. M. (2009). Water Resources and Natural Gas Production from the Marcellus Shale, USGS Fact Sheet 2009-3032, (pp. 1-6).

Stiles, J. M., Donovan, J., Dzombak, D. A., \& Capo, R. C. (2004). Geochemical cluster analysis of mine water quality within the Monongahela Basin. In National Meeting of the American Society of Mining and Reclamation (pp. 1819-1830).

Taylor, B. E., Wheeler, M. C., \& Nordstrom, D. K. (1984). Isotope composition of sulfate in acid mine drainage as measure of bacterial oxidation. Nature, 308(5), 538-541.

Toran, L., \& Harris, R. F. (1989). Interpretation of sulfur and oxygen isotopes in biological and abiological sulfide oxidation. Geochimica et Cosmochimica Acta, 53, 2341-2348. 
Trembaczowski, A., Szaran, J., \& Niezgoda, H. (2004). Investigating the provenance and seasonal variations in sulphate sulfur and oxygen isotopes of central Roztocze River, SE Poland. Water, Air, and Soil Pollution, 157, 65-84.

U.S. Environmental Protection Agency. (2002). Metals and pH TMDLs for the Monongahela River Watershed, West Virginia (pp. 1-65).

U.S. Environmental Protection Agency. (2011). Proceedings of the Technical Workshops for the Hydraulic Fracturing Study: Chemical \& Analytical Methods Proceedings of the Technical Workshops for the Hydraulic Fracturing Study: Chemical \& Analytical Methods. Environmental Protection (pp. 1-122).

Vengosh, A., \& Pankratov, I. (1998). Chloride/Bromide and Chloride/Fluoriude Ratios of Domestic Sewage Effluents and Associated Contaminated Ground Water. Ground Water, $36(5), 815-824$.

Warner, N. R., Jackson, R. B., Darrah, T. H., Osborn, S. G., Down, A., Zhao, K., ... Vengosh, A. (2012). Geochemical evidence for possible natural migration of Marcellus Formation brine to shallow aquifers in Pennsylvania. Proceedings of the National Academy of Sciences of the United States of America, 109(30), 11961-6.

Wen, X., Wu, Y., Su, J., Zhang, Y., \& Liu, F. (2005). Hydrochemical characteristics and salinity of groundwater in the Ejina Basin, Northwestern China. Environmental Geology, 48(6), $665-675$.

Williams, A. E. (1997). Stable isotope tracers: natural and anthropogenic recharge, Orange County, California. Journal of Hydrology, 201(1-4), 230-248.

West Virginia Geologic and Economic Survey (WVGES), (2012). "Selected References about Devonian Shales", http://www.wvgs.wvnet.edu/www/datastat/devshales.htm: Accessed November 2, 2012. 


\section{0 - FIGURES}

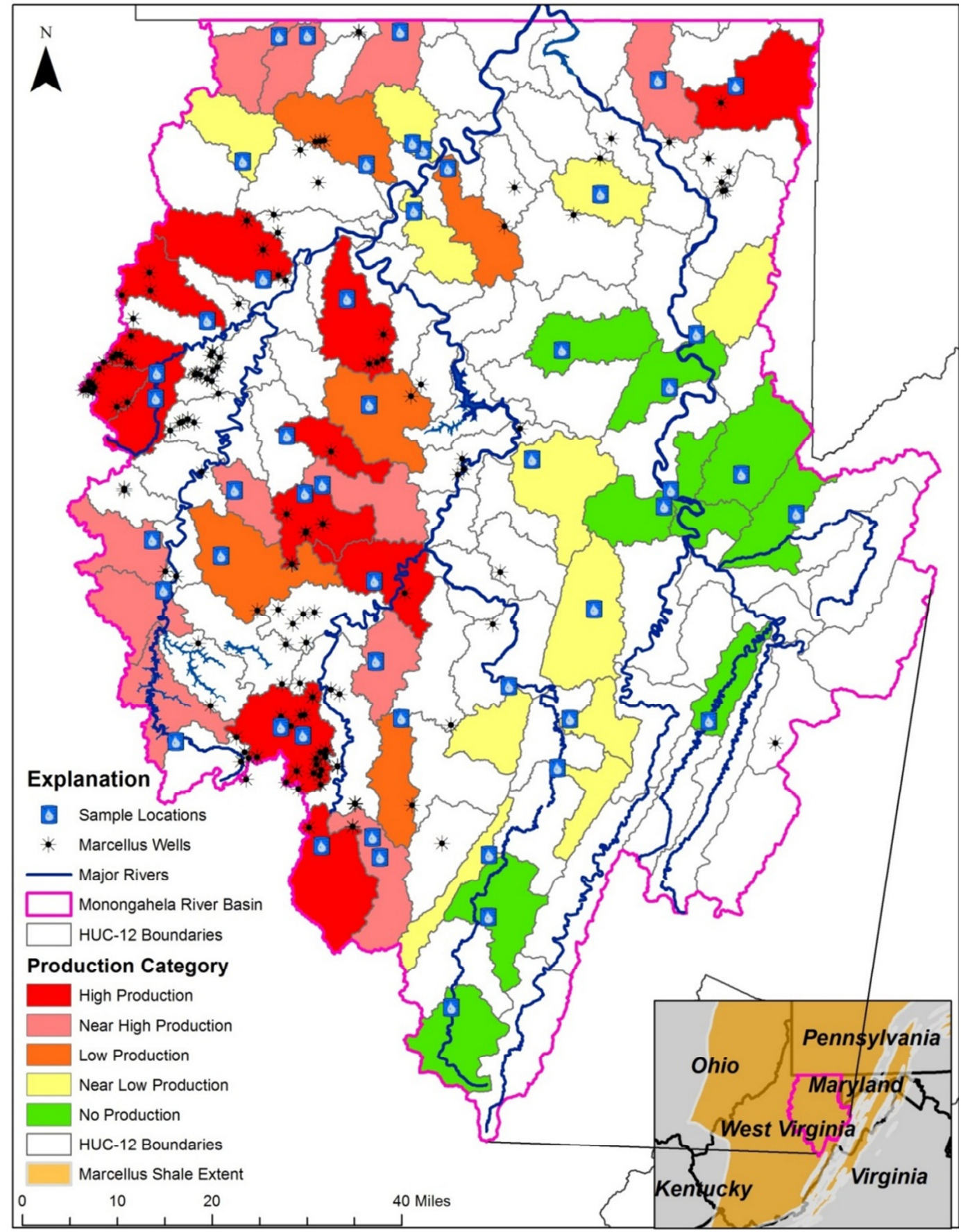

FIGURE 1 - Study area showing sample locations, HUC-12 watersheds of samples and Marcellus Shale Production categories, as well as all HUC-12's in the Monongahela River basin of West Virginia. 


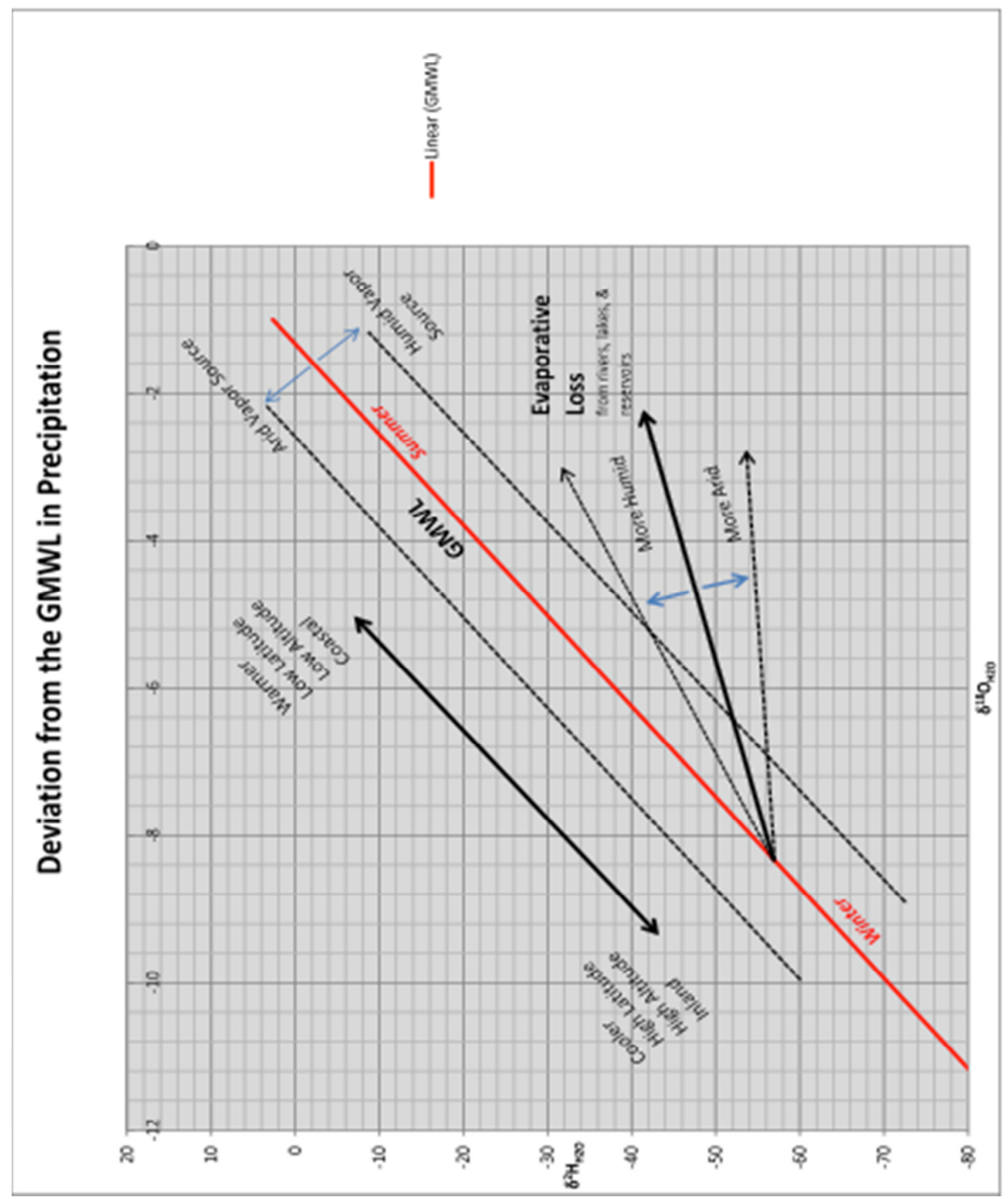

FIGURE 2 - Deviations from the global meteoric water line (GMWL) and the processes affecting deviations (Clark and Fritz, 1997) 


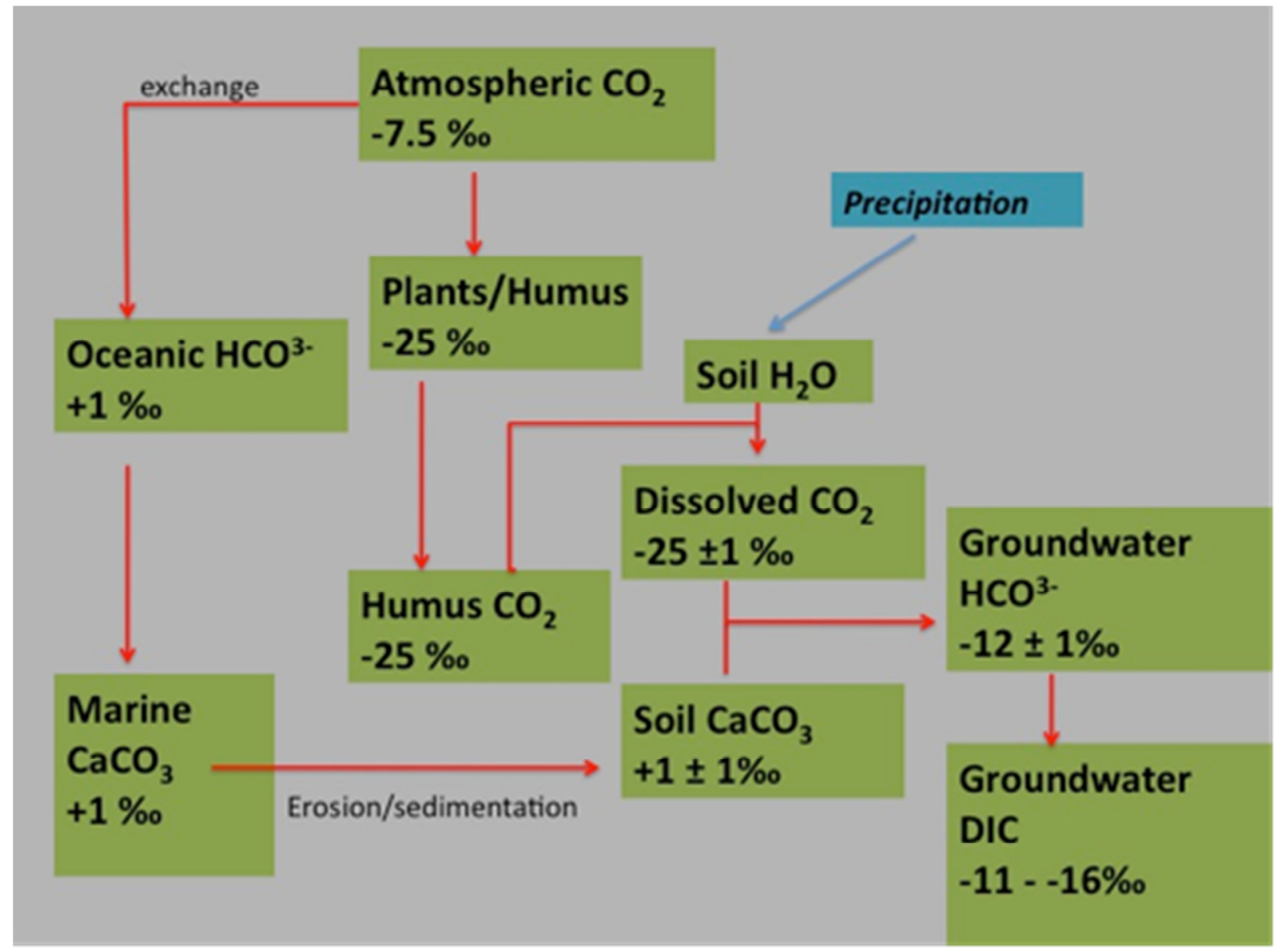

FIGURE 3 - End-member contributions to overall $\delta^{13} \mathrm{C}$ in dissolved inorganic carbon (Rozanski et al., 2001) 


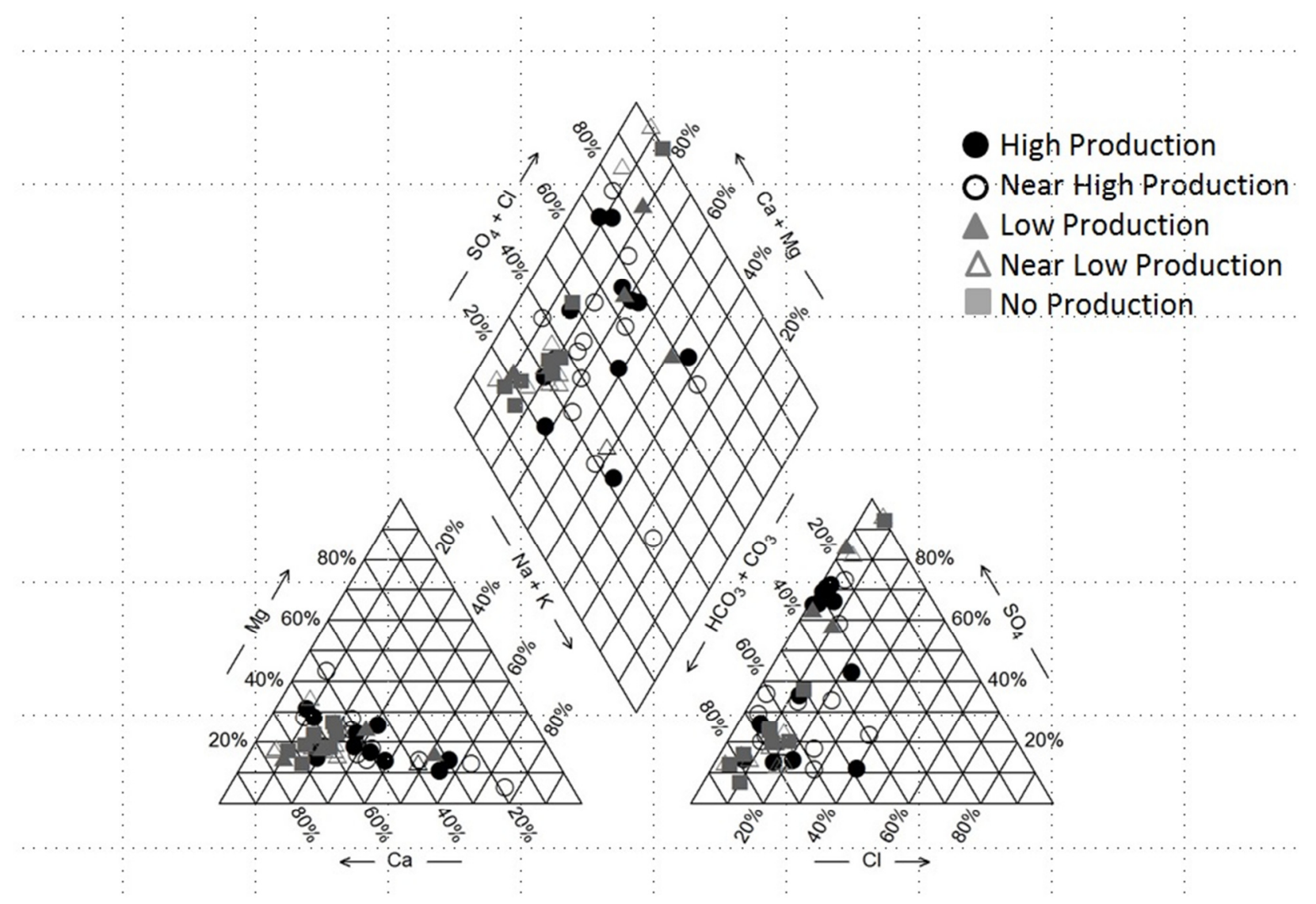

FIGURE 4 - Piper Diagram for all sample locations, subdivided by Marcellus Shale production category 


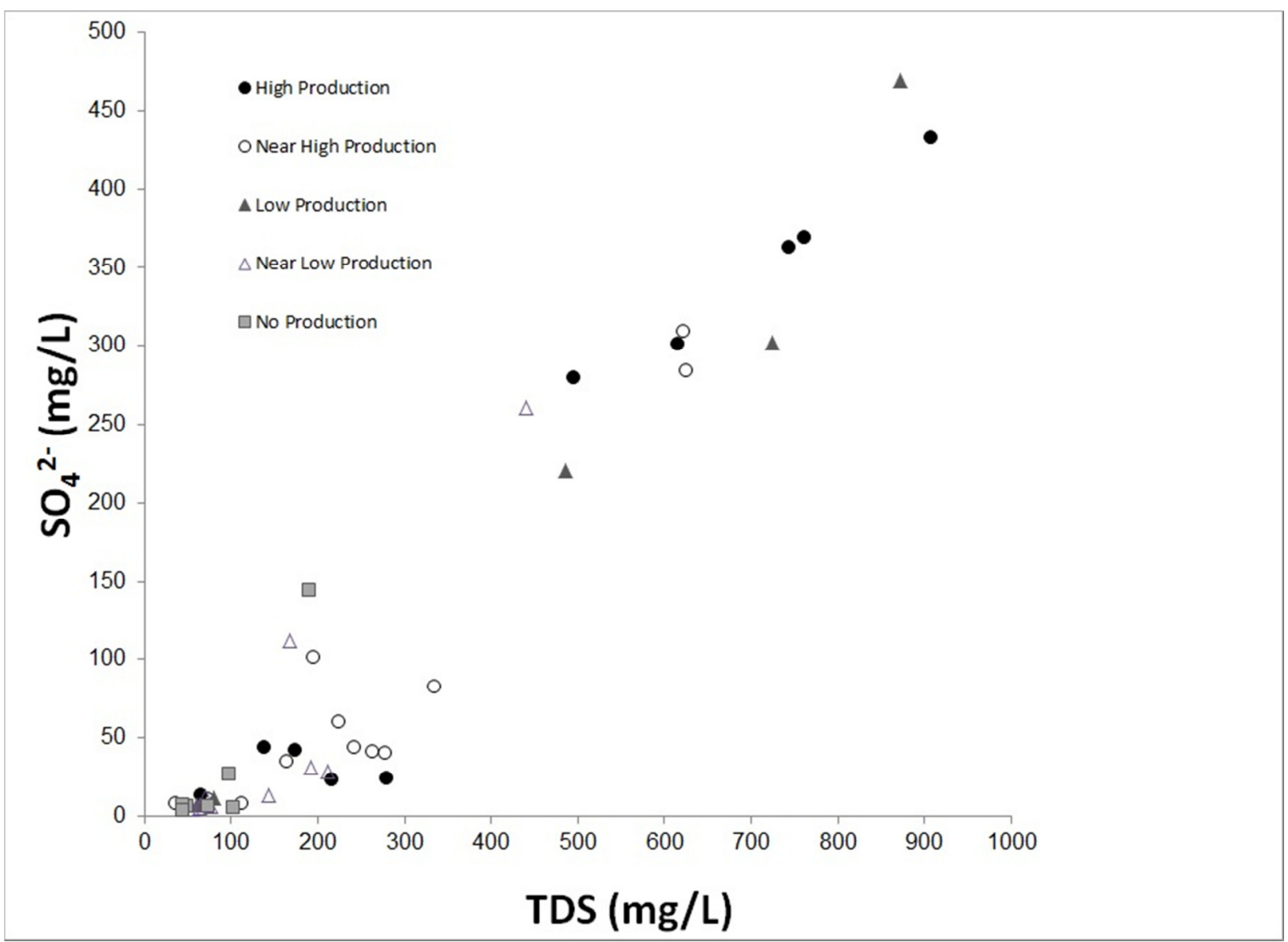

FIGURE 5 - Total dissolved solids (mg/L) versus dissolved sulfate (mg/L) for all sample locations, subdivided by Marcellus Shale production category 


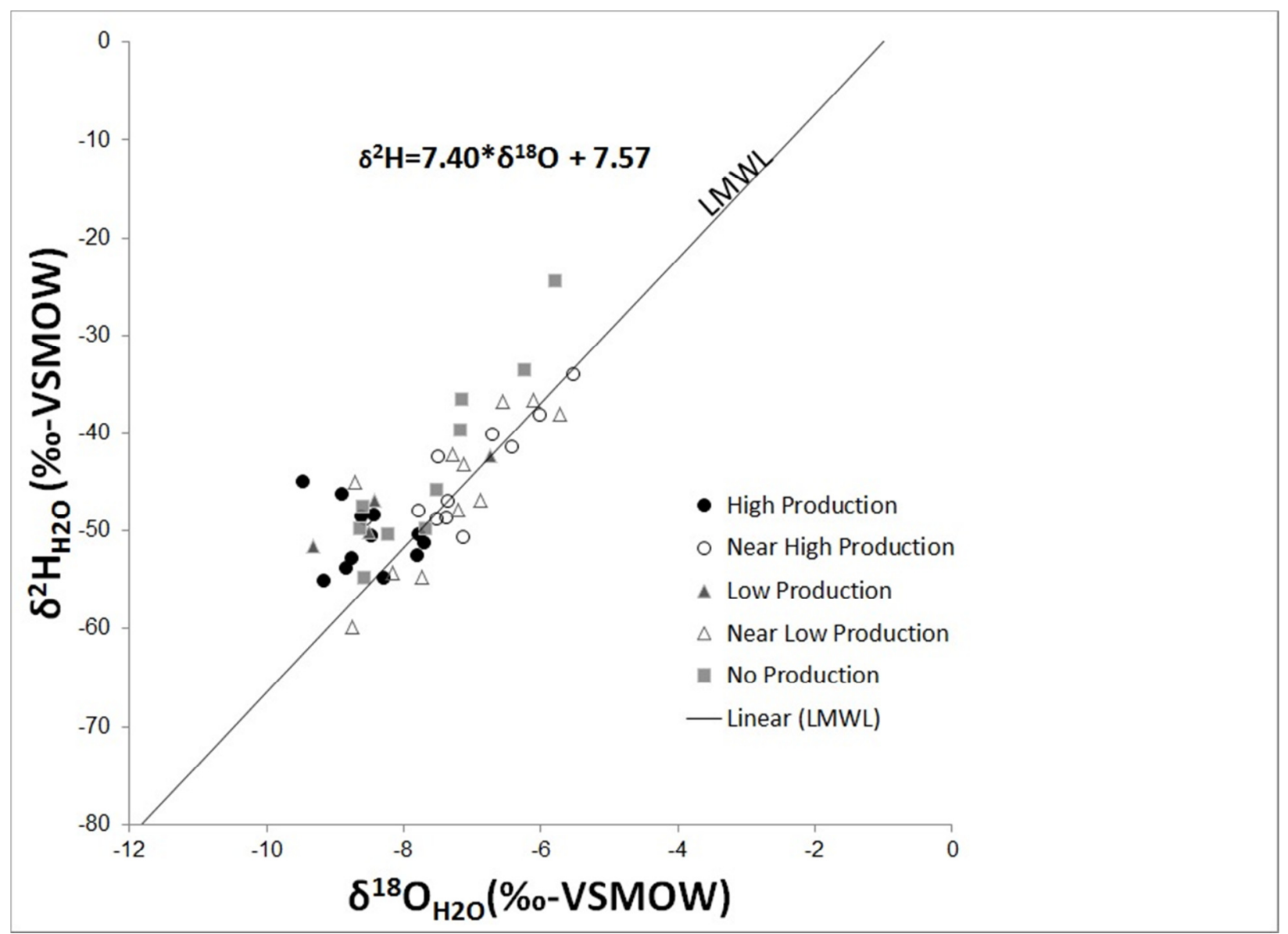

FIGURE 6 - $\delta^{18} \mathrm{O}_{\mathrm{H} 2 \mathrm{O}}$ values (\%o - VSMOW) versus $\delta^{2} \mathrm{H}_{\mathrm{H} 2 \mathrm{O}}$ values (VSMOW) for all sample locations, subdivided by Marcellus Shale production category. LMWL denotes the local meteoric water line. 


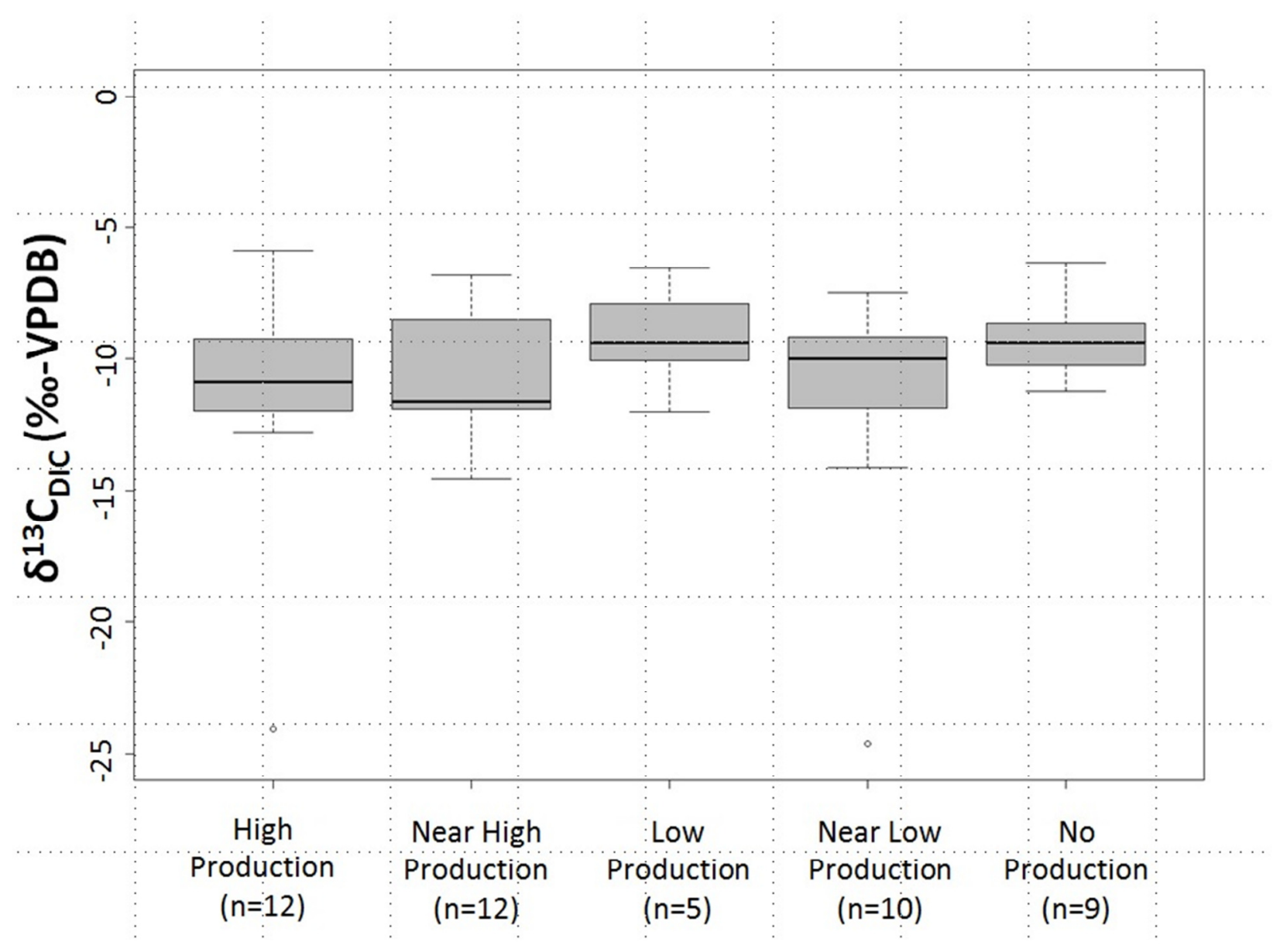

FIGURE 7 - Box and whisker plot of $\delta^{13} C_{\text {DIC }}(\%$ - VPDB) for all sample locations, subdivided by Marcellus Shale production category. 


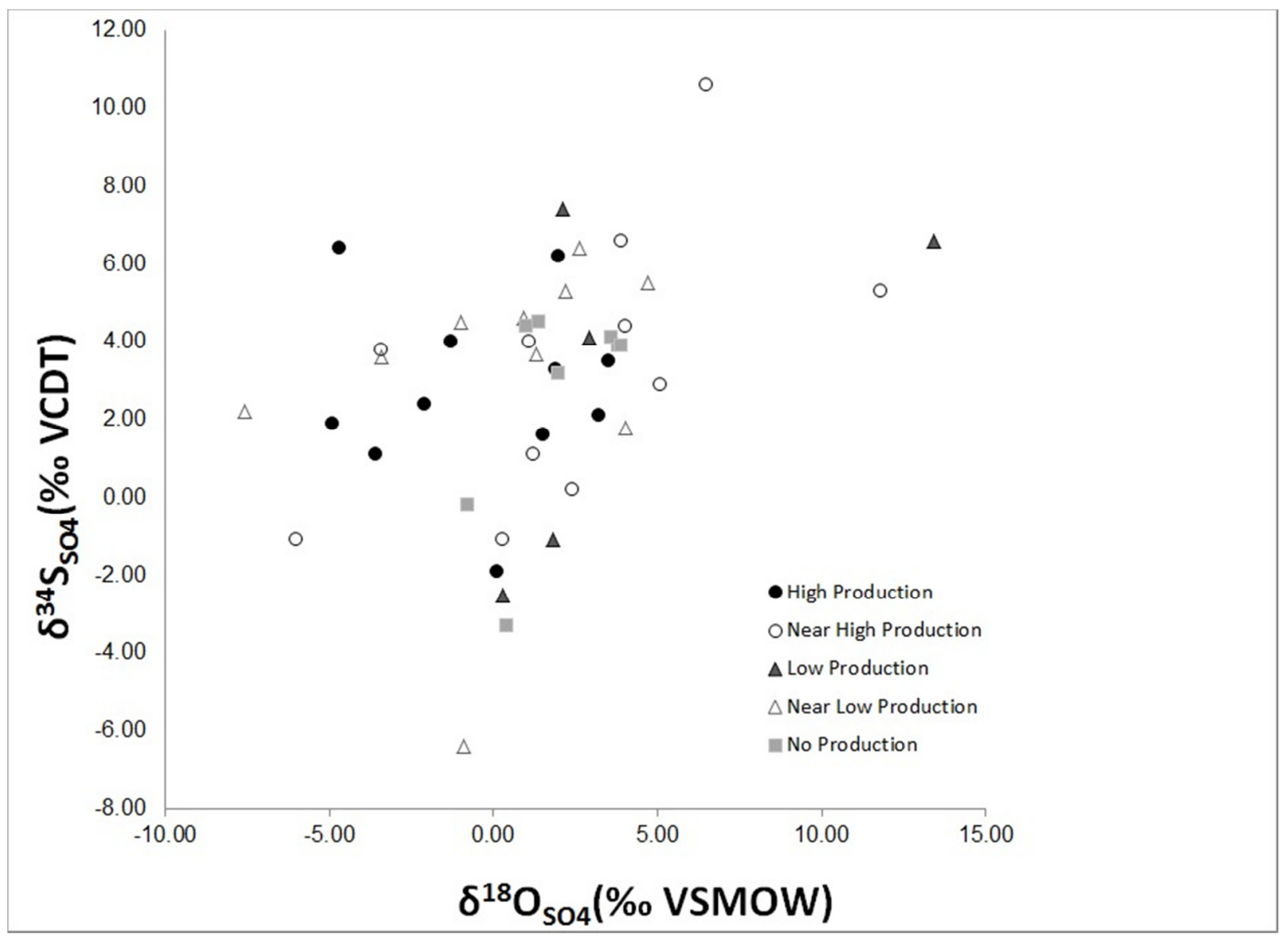

FIGURE 8 - $\delta^{18} \mathrm{O}_{\mathrm{SO} 4}\left(\%\right.$ - VSMOW) versus $\delta^{34} \mathrm{~S}_{\mathrm{SO} 4}(\% \circ$ - VCDT) values for all samples, subdivided by Marcellus Shale production category 


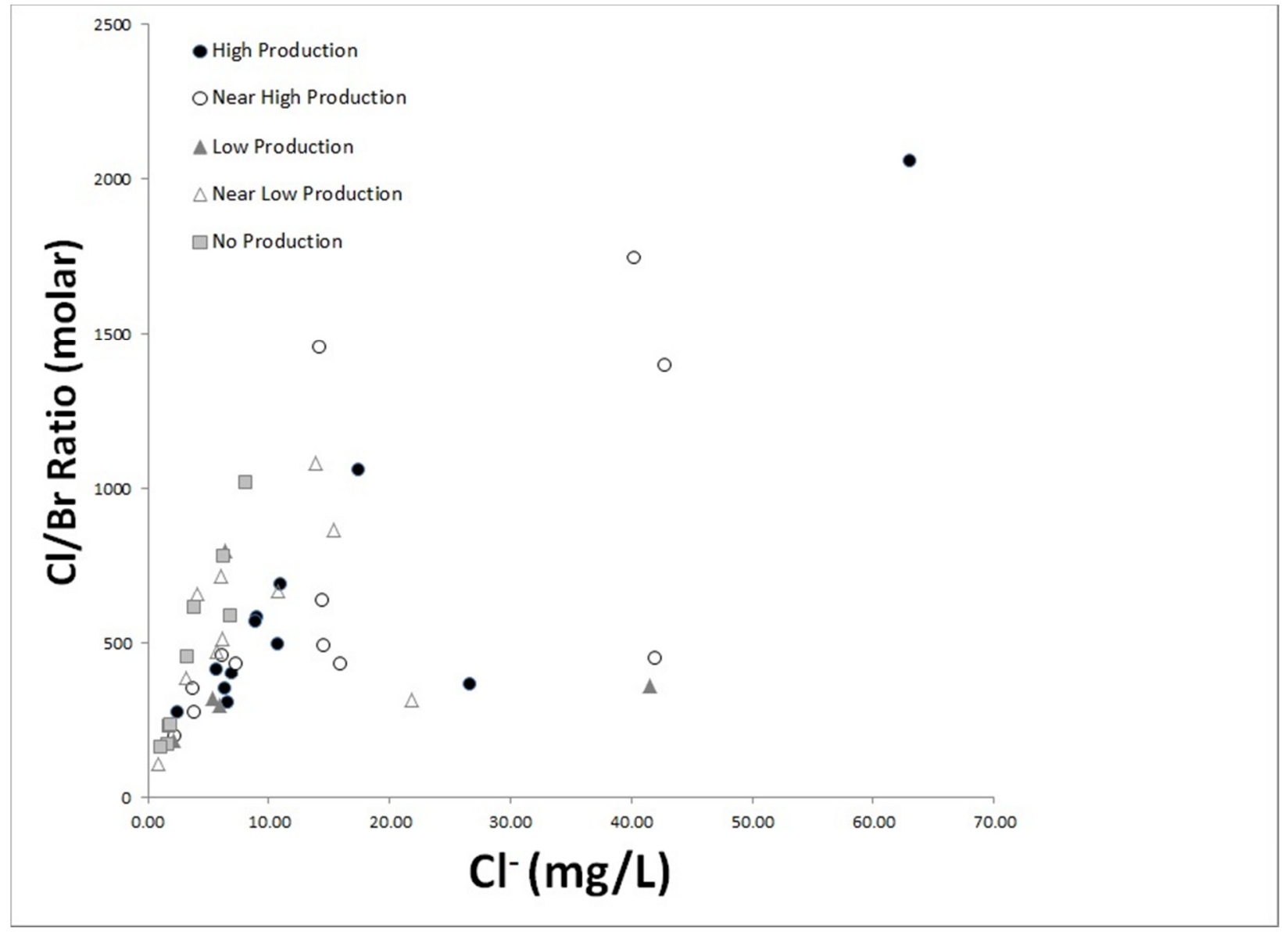

FIGURE 9 - Cl (mg/L) versus Cl/Br molar ratio for all sample locations, subdivided by Marcellus Shale production category 


\section{0 - TABLES}

TABLE 1 - Analytical Results

\begin{tabular}{|c|c|c|c|c|c|c|}
\hline Site Name/Marcellus Shale Production Category & Latitude & Longitude & $\begin{array}{c}\text { Elevation } \\
\text { (feet) }\end{array}$ & $\mathrm{pH}$ & TDS (mg/L) & $\mathrm{DIC}(\mathrm{mg} / \mathrm{L})$ \\
\hline \multicolumn{7}{|l|}{ High Production } \\
\hline HUSTEAD FK @ HWY 3/16 BR @ BOOTHSVILLE WV & 39.3931 & -80.1965 & 991 & 8.2 & 174.00 & 58.25 \\
\hline FRENCH CR @ HWY 20 BR @ FRENCH CREEK WV & 38.8854 & -80.2979 & 1467 & 7 & 72.00 & 45.35 \\
\hline LAUREL FK @ HWY 20/10 BR NR ADRIAN, WV & 38.8757 & -80.2642 & 1473 & 7.4 & 69.00 & 29.89 \\
\hline TENMILE CR @ HWY 31 BR @ MAKEN WV & 39.2756 & -80.4887 & 1004 & 7.4 & 216.00 & 139.15 \\
\hline SANDY CR @ HWY 3/4 BR NR BRANDONVILLE WV & 39.6440 & -79.6031 & 1742 & 7.7 & 139.00 & 34.79 \\
\hline SALEM CR @ HWY 5/9 BR NR MAKEN WV & 39.3048 & -80.4873 & 988 & 7.9 & 280.00 & 99.58 \\
\hline GNATTY CR @ HWY 20/20 BR @ ROMINES MLLS WV & 39.1631 & -80.2615 & 1027 & 8.2 & 908.00 & 213.30 \\
\hline TENMILE CR @ HWY 20 BR @ ROSEBUD WV & 39.3676 & -80.4101 & 951 & 8.1 & 744.00 & 168.93 \\
\hline BRUSHY FK @ HWY 42 BR NR STONEWOOD WV & 39.2315 & -80.2887 & 1010 & 8.1 & 615.00 & 118.05 \\
\hline PECKS RUN @ HWY1/13 BR @ TETER WV & 39.0595 & -80.1548 & 1414 & 7.6 & 495.00 & 101.49 \\
\hline R F BUCKHANNON R @ HWY 48 BR @ NEWLONTON W & 38.7445 & -80.2356 & 1913 & 8.6 & 66.00 & 31.79 \\
\hline BINGAMON CR @ HWY 8 BR @ PINE BLUFF WV & 39.4159 & -80.3245 & 945 & 8.4 & 762.00 & 139.96 \\
\hline Average & & & 1244 & 7.9 & 378.33 & 98.38 \\
\hline Standard Dev. & & & 343 & 0.5 & 309.43 & 59.97 \\
\hline \multicolumn{7}{|l|}{ Near High Production } \\
\hline ELK CR @ HWY 57/2 BR NR ROMINES MLLS WV & 39.1731 & -80.2345 & 1004 & 8 & 622.00 & 113.76 \\
\hline LOST CR @ HWY 27/2 BR @ LOST CREEK WV & 39.1668 & -80.3684 & 997 & 7.6 & 334.00 & 111.29 \\
\hline POLK CR @ HWY 33 BR @ WESTON WV & 39.0481 & -80.4770 & 1089 & 7.8 & 278.00 & 128.43 \\
\hline FREEMANS CR @ BR @ VALLEY CHAPEL WV & 39.1076 & -80.4943 & 1030 & 7.9 & 225.00 & 99.41 \\
\hline WEST FK R @ HWY 44 BR @ WALKERSVILLE, WV & 38.8687 & -80.4579 & 1093 & 7 & 113.00 & 62.13 \\
\hline DOLLS RUN@ @ HWY 7 BR NR CORE WV & 39.7076 & -80.1156 & 928 & 8.3 & 242.00 & 127.57 \\
\hline L F BUCKHANNON R @ HWY 9 BR @ PALACE VLYWV & 38.7548 & -80.1581 & 2103 & 7.2 & 37.00 & 14.78 \\
\hline LAUREL RUN @ HWY 73/73 BR NR LAUREL RUN WV & 39.6509 & -79.7220 & 1512 & 7.9 & 74.00 & 21.08 \\
\hline SAND RUN NR BUCKHANNON WV & 38.9640 & -80.1526 & 1588 & 7.6 & 195.00 & 29.41 \\
\hline WEST VIRGINIA FK @ HWY 7 BR @ WANNA WV & 39.7023 & -80.3004 & 1050 & 7.6 & 263.00 & 148.05 \\
\hline LFR F BUCKHANNONR @ HWY46 BR @ CZAR WV & 38.7312 & -80.1465 & 2779 & 8.2 & 165.00 & 74.18 \\
\hline MIRACLE RUN @ HWY 7 BR @ BULA WV & 39.7034 & -80.2573 & 1004 & 8 & 626.00 & 136.60 \\
\hline Average & & & 1348 & 7.8 & 264.50 & 88.89 \\
\hline Standard Dev. & & & 569 & 0.4 & 188.61 & 47.32 \\
\hline \multicolumn{7}{|l|}{ Low Production } \\
\hline WHITEDAY CR @ HWY 36 BR NR SMITHTOWN WV & 39.5473 & -80.0426 & 896 & 8.6 & 80.00 & 38.07 \\
\hline RIGHT FK @ HWY 28/1 BR NR KEDRON WV & 38.8962 & -80.1142 & 1837 & 7.4 & 60.00 & 38.02 \\
\hline SIMPSON CR @ HWY 13/13 BR @ ROSEMONT WV & 39.2681 & -80.1629 & 1007 & 8 & 872.00 & 82.05 \\
\hline HACKERS CR @ HWY 14 BR NR JANE LEW WV & 39.0890 & -80.3893 & 1047 & 8.7 & 486.00 & 110.56 \\
\hline PAW PAW CR @ HWY 17 BR @ GRANT TOWN WV & 39.5523 & -80.1673 & 945 & 7.7 & 725.00 & 168.22 \\
\hline Average & & & 1146 & 8.1 & 444.60 & 87.38 \\
\hline Standard Dev. & & & 391 & 0.6 & 368.73 & 54.70 \\
\hline
\end{tabular}


TABLE 1 (Continued) - Analytical Results

\begin{tabular}{|c|c|c|c|c|c|c|}
\hline Site Name/Marcellus Shale Production Category & Latitude & Longitude & $\begin{array}{c}\text { Elevation } \\
\text { (feet) }\end{array}$ & $\mathrm{pH}$ & TDS (mg/L) & $\mathrm{DIC}(\mathrm{mg} / \mathrm{L})$ \\
\hline \multicolumn{7}{|l|}{ Near Low Production } \\
\hline LEADING CR @ HWY 3 BR NR KERNS WV & 39.0262 & -79.8195 & 1942 & 7.2 & 63.00 & 37.81 \\
\hline CHENOWETH CR @ HWY 23 BR @ ELKINS AIRPORT & 38.8951 & -79.8565 & 1959 & 7.7 & 144.00 & 72.61 \\
\hline FILES CR @ HWY 219 BR @ BEVERLYWV & 38.8376 & -79.8756 & 1982 & 7.2 & 77.00 & 40.22 \\
\hline SALTLICK CR @ RR BR @ ROWLESBURG WV & 39.3515 & -79.6631 & 1398 & 7.6 & 71.00 & 36.13 \\
\hline MILL CR @ HWY 46 BR @ MILL CREEK WV & 38.7337 & -79.9801 & 2060 & 7.5 & 55.00 & 29.67 \\
\hline PRICKETTS CR @ HWY 73 BR @ MEADOWDALE WV & 39.4965 & -80.0945 & 915 & 8.5 & 192.00 & 89.31 \\
\hline TETER CR @ HWY 92 BR NR NESTORVILLE WV & 39.2034 & -79.9145 & 1283 & 7.6 & 64.00 & 29.48 \\
\hline DECKERS CR @ HWY 27 BR @ REEDSVILLE WV & 39.5165 & -79.8101 & 1690 & 7.4 & 441.00 & 50.59 \\
\hline ROARING CREEK AT NORTON, WV & 38.9348 & -79.9498 & 1972 & 5.4 & 168.00 & 2.89 \\
\hline PYLES FK @ HWY 250/5 BR NR METZ WV & 39.5556 & -80.3559 & 1017 & 7.8 & 211.00 & 106.01 \\
\hline Average & & & 1622 & 7.4 & 148.60 & 49.47 \\
\hline Standard Dev. & & & 434 & 0.8 & 118.35 & 31.06 \\
\hline \multicolumn{7}{|l|}{ No Production } \\
\hline CLOVER RUN@ @WY21 BR @ ST. GEORGE WV & 39.1482 & -79.7131 & 1594 & 7.2 & 44.00 & 18.23 \\
\hline MINEAR RUN @ HWY 5 BR @ ST. GEORGE WV & 39.1668 & -79.7026 & 1568 & 7.2 & 44.00 & 20.20 \\
\hline BECKY CR @ HWY 56 BR NR HUTTONSVILLE WV & 38.6601 & -79.9812 & 2149 & 7.7 & 73.00 & 38.31 \\
\hline TYGART VLYR @ HWY 15 BR @ VALLEY HEAD WV & 38.5526 & -80.0373 & 2349 & 8 & 102.00 & 65.62 \\
\hline HORSESHOE RUN @ HWY 9 BR @ LEAD MINE WV & 39.1857 & -79.5948 & 1791 & 7.5 & 49.00 & 19.52 \\
\hline BUFFALO CREEK NEAR ROWLESBURG, WV & 39.2887 & -79.7042 & 1647 & 7.3 & 44.00 & 26.36 \\
\hline N FK BLACKWATER R @ HWY 27 BR @ COKETON WV & 39.1390 & -79.5109 & 2854 & 8.1 & 98.00 & 34.35 \\
\hline GLADY FK @ HWY 33 BR @ ALPENA WV & 38.8926 & -79.6442 & 2684 & 7.2 & 45.00 & 19.90 \\
\hline SANDY CR @ HWY 92/14 BR @ EVANSVILLE WV & 39.3329 & -79.8684 & 1335 & 4.8 & 190.00 & 8.07 \\
\hline Average & & & 1997 & 7.2 & 76.56 & 27.84 \\
\hline Standard Dev. & & & 536 & 1.0 & 48.64 & 16.79 \\
\hline \multicolumn{7}{|l|}{ Not Used for Analysis } \\
\hline INDIAN CR @ HWY 45/2 BR @ OSGOOD WV & 39.569 & -80.080 & 974 & 8.3 & 3300.00 & 58.00 \\
\hline INDIAN CREEK AT CROWN, WV & 39.577 & -80.097 & 942 & 8.3 & 4380.00 & 80.64 \\
\hline
\end{tabular}


TABLE 1 (Continued) - Analytical Results

\begin{tabular}{|c|c|c|c|c|c|c|c|c|}
\hline Site Name/Marcellus Shale Production Category & $\begin{array}{c}\mathrm{Ca}^{2+} \\
(\mathrm{mg} / \mathrm{L})\end{array}$ & $\begin{array}{c}\mathrm{Na}^{+} \\
(\mathrm{mg} / \mathrm{L})\end{array}$ & $\begin{array}{c}\mathrm{K}^{+} \\
(\mathrm{mg} / \mathrm{L})\end{array}$ & $\begin{array}{l}\mathrm{Mg}^{2+} \\
(\mathrm{mg} / \mathrm{L})\end{array}$ & $\begin{array}{l}\mathrm{HCO}^{-} \\
(\mathrm{mg} / \mathrm{L})\end{array}$ & $\begin{array}{l}\mathrm{SO}_{4}{ }^{2-} \\
(\mathrm{mg} / \mathrm{L})\end{array}$ & $\begin{array}{c}\mathrm{Cl}^{-} \\
(\mathrm{mg} / \mathrm{L})\end{array}$ & $\begin{array}{c}\mathrm{Br} \\
(\mathrm{mg} / \mathrm{L})\end{array}$ \\
\hline \multicolumn{9}{|l|}{ High Production } \\
\hline HUSTEAD FK @ HWY3/16 BR @ BOOTHSVILLE WV & 37.70 & 8.96 & 2.81 & 6.71 & 79.49 & 42.00 & 11.00 & 0.04 \\
\hline FRENCH CR @ HWY 20 BR @ FRENCH CREEK WV & 14.60 & 4.37 & 1.76 & 2.63 & 52.19 & 6.36 & 5.69 & 0.03 \\
\hline LAUREL FK @ HWY 20/10 BR NR ADRIAN, WV & 13.20 & 3.75 & 1.34 & 1.80 & 37.60 & 5.84 & 6.59 & 0.05 \\
\hline TENMILE CR @ HWY31 BR @ MAKEN WV & 44.40 & 24.60 & 3.92 & 9.36 & 173.98 & 23.00 & 9.02 & 0.04 \\
\hline SANDY CR @ HWY 3/4 BR NR BRANDONVILLE WV & 23.60 & 12.90 & 2.36 & 6.48 & 46.29 & 43.70 & 17.40 & 0.04 \\
\hline SALEMCR @ HWY 5/9 BR NR MAKEN WV & 46.70 & 41.20 & 5.07 & 8.28 & 133.99 & 23.70 & 63.10 & 0.07 \\
\hline GNATTY CR @ HWY 20/20 BR @ ROMINES MLLS WV & 126.00 & 102.00 & 3.93 & 44.90 & 285.97 & 433.00 & 6.94 & 0.04 \\
\hline TENMILE CR @ HWY 20 BR @ ROSEBUD WV & 125.00 & 93.80 & 4.72 & 25.00 & 227.97 & 363.00 & 10.80 & 0.05 \\
\hline BRUSHY FK @ HWY 42 BR NR STONEWOOD WV & 120.00 & 17.60 & 4.33 & 37.20 & 159.98 & 301.00 & 6.39 & 0.04 \\
\hline PECKS RUN @ HWY 1/13 BR @ TETER WV & 105.00 & 22.80 & 3.59 & 29.80 & 132.99 & 280.00 & 8.86 & 0.04 \\
\hline R F BUCKHANNON R @ HWY 48 BR @ NEWLONTON WI & 7.68 & 14.00 & 0.78 & 1.45 & 43.70 & 13.30 & 2.44 & 0.02 \\
\hline BINGAMON CR @ HWY 8 BR @ PINE BLUFF WV & 69.70 & 151.00 & 3.45 & 20.20 & 191.98 & 369.00 & 26.60 & 0.16 \\
\hline Average & 61.13 & 41.42 & 3.17 & 16.15 & 130.51 & 158.66 & 14.57 & 0.05 \\
\hline Standard Dev. & 46.24 & 47.70 & 1.37 & 14.91 & 81.03 & 172.51 & 16.55 & 0.04 \\
\hline \multicolumn{9}{|l|}{ Near High Production } \\
\hline ELK CR @ HWY 57/2 BR NR ROMINES MLLS WV & 97.10 & 50.00 & 3.10 & 32.80 & 153.98 & 309.00 & 7.29 & 0.04 \\
\hline LOST CR @ HWY 27/2 BR @ LOST CREEK WV & 65.00 & 26.70 & 3.55 & 16.30 & 144.98 & 82.20 & 40.30 & 0.05 \\
\hline POLK CR @ HWY 33 BR @ WESTON WV & 53.10 & 25.70 & 4.90 & 13.70 & 169.98 & 40.20 & 42.80 & 0.07 \\
\hline FREEMANS CR @ BR @ VALLEY CHAPEL WV & 48.10 & 6.25 & 3.85 & 13.10 & 133.99 & 60.10 & 3.82 & 0.03 \\
\hline WEST FK R @ HWY 44 BR @ WALKERSVILLE, WV & 21.00 & 11.90 & 2.76 & 3.74 & 70.89 & 8.32 & 15.90 & 0.08 \\
\hline DOLLS RUN @ HWY 7 BR NR CORE WV & 43.20 & 32.20 & 2.82 & 9.46 & 173.98 & 43.90 & 14.60 & 0.07 \\
\hline LF BUCKHANNON R @ HWY9 BR @ PALACE VLY WV & 5.51 & 2.65 & 0.66 & 1.55 & 18.00 & 7.64 & 2.21 & 0.03 \\
\hline LAUREL RUN @ HWY 73/73 BR NR LAUREL RUN WV & 11.80 & 8.29 & 0.90 & 1.93 & 25.90 & 11.10 & 14.20 & 0.02 \\
\hline SAND RUN NR BUCKHANNON WV & 28.90 & 4.24 & 2.18 & 15.60 & 38.60 & 101.00 & 6.13 & 0.03 \\
\hline WEST VIRGINIA FK @ HWY 7 BR @ WANNA WV & 35.10 & 49.80 & 2.86 & 7.91 & 193.98 & 41.30 & 14.40 & 0.05 \\
\hline LF R F BUCKHANNON R @ HWY 46 BR @ CZAR WV & 9.63 & 45.00 & 1.13 & 1.61 & 100.99 & 34.50 & 3.73 & 0.02 \\
\hline MIRACLE RUN@ @ HWY 7 BR @ BULA WV & 50.30 & 151.00 & 3.09 & 16.40 & 183.98 & 284.00 & 42.00 & 0.21 \\
\hline Average & 39.06 & 34.48 & 2.65 & 11.18 & 117.44 & 85.27 & 17.28 & 0.06 \\
\hline Standard Dev. & 26.36 & 40.71 & 1.26 & 8.99 & 64.34 & 102.75 & 15.48 & 0.05 \\
\hline \multicolumn{9}{|l|}{ Low Production } \\
\hline WHITEDAY CR @ HWY 36 BR NR SMITHTOWN WV & 16.90 & 5.15 & 1.76 & 2.76 & 52.29 & 11.80 & 6.38 & 0.02 \\
\hline RIGHT FK @ HWY 28/1 BR NR KEDRON WV & 15.60 & 2.02 & 1.04 & 1.72 & 47.99 & 6.70 & 2.14 & 0.03 \\
\hline SIMPSON CR @ HWY 13/13 BR @ ROSEMONT WV & 145.00 & 56.10 & 3.53 & 41.20 & 110.99 & 470.00 & 5.39 & 0.04 \\
\hline HACKERS CR @ HWY 14 BR NR JANE LEW WV & 74.90 & 50.00 & 3.31 & 22.40 & 151.98 & 220.00 & 5.96 & 0.05 \\
\hline PAW PAW CR @ HWY 17 BR @ GRANT TOWN WV & 75.20 & 134.00 & 3.38 & 21.30 & 222.98 & 302.00 & 41.50 & 0.26 \\
\hline Average & 65.52 & 49.45 & 2.60 & 17.88 & 117.25 & 202.10 & 12.27 & 0.08 \\
\hline Standard Dev. & 53.28 & 53.40 & 1.13 & 16.32 & 73.21 & 197.78 & 16.42 & 0.10 \\
\hline
\end{tabular}


TABLE 1 (Continued) - Analytical Results

\begin{tabular}{|c|c|c|c|c|c|c|c|c|}
\hline Site Name/Marcellus Shale Production Category & $\begin{array}{c}\mathrm{Ca}^{2+} \\
(\mathrm{mg} / \mathrm{L})\end{array}$ & $\begin{array}{c}\mathrm{Na}^{+} \\
(\mathrm{mg} / \mathrm{L})\end{array}$ & $\begin{array}{c}\mathrm{K}^{+} \\
(\mathrm{mg} / \mathrm{L})\end{array}$ & $\begin{array}{c}\mathrm{Mg}^{2+} \\
(\mathrm{mg} / \mathrm{L})\end{array}$ & $\begin{array}{l}\mathrm{HCO}^{-} \\
(\mathrm{mg} / \mathrm{L})\end{array}$ & $\begin{array}{l}\mathrm{SO}_{4}{ }^{2-} \\
(\mathrm{mg} / \mathrm{L})\end{array}$ & $\begin{array}{c}\mathrm{Cl}^{-} \\
(\mathrm{mg} / \mathrm{L})\end{array}$ & $\begin{array}{c}\mathrm{Br} \\
(\mathrm{mg} / \mathrm{L})\end{array}$ \\
\hline \multicolumn{9}{|l|}{ Near Low Production } \\
\hline LEADING CR @ HWY 3 BR NR KERNS WV & 12.90 & 4.61 & 1.98 & 2.47 & 46.49 & 5.24 & 6.16 & 0.03 \\
\hline CHENOWETH CR @ HWY 23 BR @ ELKINS AIRPORT & 28.40 & 12.70 & 1.93 & 4.20 & 95.69 & 13.50 & 15.40 & 0.04 \\
\hline FILES CR @ HWY 219 BR @ BEVERLY WV & 13.30 & 3.26 & 1.29 & 2.16 & 48.69 & 5.86 & 3.11 & 0.02 \\
\hline SALTLICK CR @ RR BR @ ROWLESBURG WV & 15.60 & 4.02 & 1.33 & 3.30 & 47.59 & 12.60 & 6.06 & 0.02 \\
\hline MLL CR @ HWY 46 BR @ MLL CREEK WV & 12.60 & 0.89 & 0.92 & 1.72 & 38.50 & 4.17 & 0.87 & 0.02 \\
\hline PRICKETTS CR @ HWY73 BR @ MEADOWDALE WV & 40.00 & 16.70 & 2.59 & 6.56 & 122.99 & 31.10 & 13.90 & 0.03 \\
\hline TETER CR @ HWY 92 BR NR NESTORVILLE WV & 12.30 & 3.35 & 1.40 & 2.15 & 38.80 & 7.45 & 4.09 & 0.01 \\
\hline DECKERS CR @ HWY 27 BR @ REEDSVILLE WV & 104.00 & 8.31 & 5.12 & 13.50 & 64.59 & 261.00 & 10.70 & 0.04 \\
\hline ROARING CREEK AT NORTON, WV & 28.30 & 3.99 & 1.33 & 10.00 & 0.40 & 112.00 & 5.68 & 0.03 \\
\hline PYLES FK @ HWY 250/5 BR NR METZ WV & 28.80 & 40.50 & 1.88 & 5.55 & 140.98 & 28.60 & 21.80 & 0.16 \\
\hline Average & 29.62 & 9.83 & 1.98 & 5.16 & 64.47 & 48.15 & 8.78 & 0.04 \\
\hline Standard Dev. & 27.84 & 11.83 & 1.20 & 3.90 & 42.88 & 81.47 & 6.53 & 0.04 \\
\hline \multicolumn{9}{|l|}{ No Production } \\
\hline CLOVER RUN @ HWY21 BR @ ST. GEORGE WV & 6.63 & 2.06 & 1.06 & 1.81 & 22.50 & 5.69 & 1.73 & 0.02 \\
\hline MINEAR RUN @ HWY 5 BR @ ST. GEORGE WV & 6.50 & 1.72 & 1.26 & 1.89 & 24.40 & 5.98 & 1.88 & 0.02 \\
\hline BECKY CR @ HWY 56 BR NR HUTTONSVILLE WV & 15.20 & 1.93 & 1.08 & 2.17 & 50.79 & 5.79 & 1.61 & 0.02 \\
\hline TYGART VLYR @ HWY 15 BR @ VALLEY HEAD WV & 25.70 & 6.26 & 1.14 & 2.85 & 88.39 & 5.52 & 6.24 & 0.02 \\
\hline HORSESHOE RUN @ HWY 9 BR @ LEAD MINE WV & 7.33 & 2.45 & 1.23 & 1.80 & 25.40 & 5.95 & 3.81 & 0.01 \\
\hline BUFFALO CREEK NEAR ROWLESBURG, WV & 8.94 & 2.91 & 1.36 & 1.63 & 32.80 & 6.76 & 3.25 & 0.02 \\
\hline N FK BLACKWATER R @ HWY 27 BR @ COKETON WV & 21.40 & 5.04 & 1.60 & 4.49 & 46.69 & 26.80 & 6.79 & 0.03 \\
\hline GLADY FK @ HWY 33 BR @ ALPENA WV & 7.30 & 1.27 & 0.88 & 1.26 & 24.40 & 3.42 & 1.10 & 0.02 \\
\hline SANDY CR @ HWY 92/14 BR @ EVANSVILLE WV & 31.20 & 7.50 & 2.00 & 6.78 & 8.30 & 144.00 & 8.15 & 0.02 \\
\hline Average & 14.47 & 3.46 & 1.29 & 2.74 & 35.96 & 23.32 & 3.84 & 0.02 \\
\hline Standard Dev. & 9.44 & 2.24 & 0.33 & 1.79 & 23.50 & 45.80 & 2.60 & 0.00 \\
\hline \multicolumn{9}{|l|}{ Not Used for Analysis } \\
\hline INDIAN CR @ HWY 45/2 BR @ OSGOOD WV & 227.00 & 697.00 & 7.05 & 77.40 & 289.97 & 2040.00 & 71.20 & 0.46 \\
\hline INDIAN CREEK AT CROWN, WV & 291.00 & 949.00 & 8.85 & 86.30 & 400.96 & 2640.00 & 100.00 & 0.69 \\
\hline
\end{tabular}


TABLE 1 (Continued) - Analytical Results

\begin{tabular}{|c|c|c|c|c|c|c|c|}
\hline Site Name/Marcellus Shale Production Category & $\mathrm{Cl} / \mathrm{Br}$ Ratio (Molar) & $\begin{array}{l}\mathrm{Sr} \\
(\mathrm{mg} / \mathrm{L})\end{array}$ & $\mathrm{Mn}(\mathrm{mg} / \mathrm{L})$ & $\mathrm{Al}(\mathrm{mg} / \mathrm{L}$ & $\begin{array}{l}\mathrm{Fe} \\
(\mathrm{mg} / \mathrm{L})\end{array}$ & Silica $(\mathrm{mg} / \mathrm{L})$ & $\mathrm{Ba}(\mathrm{mg} / \mathrm{L})$ \\
\hline \multicolumn{8}{|l|}{ High Production } \\
\hline HUSTEAD FK @ HWY 3/16 BR @ BOOTHSVILLE WV & 689 & 0.12 & 0.01 & 0.01 & 0.02 & 3.98 & 0.06 \\
\hline FRENCH CR @ HWY 20 BR @ FRENCH CREEK WV & 414 & 0.06 & 0.16 & 0.01 & 0.51 & 4.87 & 0.05 \\
\hline LAUREL FK @ HWY 20/10 BR NR ADRIAN, WV & 309 & 0.07 & 0.03 & 0.04 & 0.16 & 3.66 & 0.07 \\
\hline TENMILE CR @ HWY 31 BR @ MAKEN WV & 581 & 0.25 & 0.28 & 0.01 & 0.05 & 4.23 & 0.10 \\
\hline SANDY CR @ HWY 3/4 BR NR BRANDONVILLE WV & 1060 & 0.07 & 0.02 & 0.01 & 0.15 & 4.47 & 0.05 \\
\hline SALEM CR @ HWY 5/9 BR NR MAKEN WV & 2061 & 0.25 & 0.05 & 0.01 & 0.03 & 3.06 & 0.09 \\
\hline GNATTY CR @ HWY 20/20 BR @ ROMINES MLLS WV & 401 & 0.96 & 0.06 & 0.01 & 0.01 & 4.45 & 0.05 \\
\hline TENMILE CR @ HWY 20 BR @ ROSEBUD WV & 497 & 1.72 & 0.08 & 0.01 & 0.01 & 6.32 & 0.07 \\
\hline BRUSHY FK @ HWY 42 BR NR STONEWOOD WV & 351 & 0.57 & 0.05 & 0.01 & 0.01 & 4.06 & 0.07 \\
\hline PECKS RUN@ @ HWY 1/13 BR @ TETER WV & 571 & 0.45 & 0.47 & 0.06 & 0.04 & 1.69 & 0.06 \\
\hline R F BUCKHANNON R @ HWY 48 BR @ NEWLONTON WV & 275 & 0.03 & 0.02 & 0.01 & 0.07 & 2.22 & 0.04 \\
\hline BINGAMON CR @ HWY 8 BR @ PINE BLUFF WV & 366 & 0.93 & 0.02 & 0.01 & 0.01 & 2.64 & 0.07 \\
\hline Average & 631 & 0.46 & 0.10 & 0.02 & 0.09 & 3.80 & 0.06 \\
\hline Standard Dev. & 499 & 0.52 & 0.14 & 0.02 & 0.14 & 1.26 & 0.02 \\
\hline \multicolumn{8}{|l|}{ Near High Production } \\
\hline ELK CR @ HWY 57/2 BR NR ROMINES MLLLS WV & 432 & 0.63 & 0.05 & 0.01 & 0.02 & 4.58 & 0.05 \\
\hline LOST CR @ HWY 27/2 BR @ LOST CREEK WV & 1747 & 0.23 & 0.35 & 0.00 & 0.04 & 4.12 & 0.10 \\
\hline POLK CR @ HWY 33 BR @ WESTON WV & 1398 & 0.22 & 0.26 & 0.00 & 0.06 & 3.16 & 0.07 \\
\hline FREEMANS CR @ BR @ VALLEY CHAPEL WV & 278 & 0.20 & 0.13 & 0.01 & 0.03 & 3.75 & 0.07 \\
\hline WEST FK R @ HWY 44 BR @ WALKERSVILLE, WV & 432 & 0.12 & 0.44 & 0.00 & 0.60 & 3.72 & 0.08 \\
\hline DOLLS RUN@ @ HWY 7 BR NR CORE WV & 491 & 0.23 & 0.02 & 0.01 & 0.02 & 4.99 & 0.07 \\
\hline LF BUCKHANNON R @ HWY9 BR @ PALACE VLYWV & 199 & 0.02 & 0.01 & 0.01 & 0.01 & 2.67 & 0.04 \\
\hline LAUREL RUN @ HWY 73/73 BR NR LAUREL RUN WV & 1455 & 0.03 & 0.02 & 0.02 & 0.03 & 2.95 & 0.05 \\
\hline SAND RUN NR BUCKHANNON WV & 461 & 0.05 & 0.02 & 0.01 & 0.06 & 4.04 & 0.05 \\
\hline WEST VIRGINIA FK @ HWY 7 BR @ WANNA WV & 636 & 0.25 & 0.24 & 0.01 & 0.09 & 3.08 & 0.08 \\
\hline LF R F BUCKHANNON R @ HWY 46 BR @ CZAR WV & 350 & 0.05 & 0.01 & 0.02 & 0.09 & 3.27 & 0.04 \\
\hline MIRACLE RUN@ @ HWY7 BR @ BULA WV & 451 & 0.40 & 0.05 & 0.01 & 0.04 & 1.68 & 0.07 \\
\hline Average & 694 & 0.20 & 0.13 & 0.01 & 0.09 & 3.50 & 0.06 \\
\hline Standard Dev. & 523 & 0.18 & 0.15 & 0.01 & 0.16 & 0.90 & 0.02 \\
\hline \multicolumn{8}{|l|}{ Low Production } \\
\hline WHITEDAY CR @ HWY 36 BR NR SMITHTOWN WV & 799 & 0.07 & 0.01 & 0.03 & 0.06 & 2.05 & 0.06 \\
\hline RIGHT FK @ HWY 28/1 BR NR KEDRON WV & 186 & 0.04 & 0.02 & 0.01 & 0.18 & 2.56 & 0.07 \\
\hline SIMPSON CR @ HWY 13/13 BR @ ROSEMONT WV & 320 & 0.97 & 0.12 & 0.04 & 0.01 & 9.93 & 0.04 \\
\hline HACKERS CR @ HWY 14 BR NR JANE LEW WV & 299 & 0.49 & 0.07 & 0.01 & 0.01 & 3.86 & 0.06 \\
\hline PAW PAW CR @ HWY17 BR @ GRANT TOWNWV & 361 & 0.69 & 0.38 & 0.01 & 0.02 & 3.65 & 0.07 \\
\hline Average & 393 & 0.45 & 0.12 & 0.02 & 0.05 & 4.41 & 0.06 \\
\hline Standard Dev. & 236 & 0.40 & 0.15 & 0.01 & 0.07 & 3.18 & 0.01 \\
\hline
\end{tabular}


TABLE 1 (Continued) - Analytical Results

\begin{tabular}{|c|c|c|c|c|c|c|c|}
\hline Site Name/Marcellus Shale Production Category & Cl/Br Ratio (Molar) & $\begin{array}{l}\mathrm{Sr} \\
(\mathrm{mg} / \mathrm{L})\end{array}$ & $\mathrm{Mn}(\mathrm{mg} / \mathrm{L})$ & Al $(\mathrm{mg} / \mathrm{L}$ & $\begin{array}{l}\mathrm{Fe} \\
(\mathrm{mg} / \mathrm{L})\end{array}$ & Silica $(\mathrm{mg} / \mathrm{L})$ & $\mathrm{Ba}(\mathrm{mg} / \mathrm{L})$ \\
\hline \multicolumn{8}{|l|}{ Near Low Production } \\
\hline LEADING CR @ HWY 3 BR NR KERNS WV & 514 & 0.05 & 0.11 & 0.02 & 0.66 & 2.20 & 0.06 \\
\hline CHENOWETH CR @ HWY 23 BR @ ELKINS AIRPORT & 868 & 0.11 & 0.04 & 0.00 & 0.19 & 4.45 & 0.06 \\
\hline FILES CR @ HWY 219 BR @ BEVERLYWV & 389 & 0.04 & 0.02 & 0.00 & 0.09 & 3.94 & 0.05 \\
\hline SALTLICK CR @ RR BR @ ROWLESBURG WV & 719 & 0.09 & 0.00 & 0.00 & 0.01 & 4.27 & 0.06 \\
\hline MLL CR @ HWY 46 BR @ MILL CREEK WV & 109 & 0.03 & 0.01 & 0.02 & 0.07 & 2.83 & 0.04 \\
\hline PRICKETTS CR @ HWY73 BR @ MEADOWDALE WV & 1080 & 0.15 & 0.01 & 0.01 & 0.03 & 2.91 & 0.08 \\
\hline TETER CR @ HWY 92 BR NR NESTORVILLE WV & 658 & 0.04 & 0.01 & 0.00 & 0.10 & 3.36 & 0.04 \\
\hline DECKERS CR @ HWY 27 BR @ REEDSVILLE WV & 670 & 0.28 & 0.17 & 0.00 & 0.03 & 2.55 & 0.04 \\
\hline ROARING CREEK AT NORTON, WV & 474 & 0.07 & 0.35 & 0.10 & 0.03 & 7.01 & 0.05 \\
\hline PYLES FK @ HWY 250/5 BR NR METZWV & 315 & 0.20 & 0.05 & 0.02 & 0.09 & 4.63 & 0.08 \\
\hline Average & 580 & 0.11 & 0.08 & 0.02 & 0.13 & 3.82 & 0.06 \\
\hline Standard Dev. & 281 & 0.08 & 0.11 & 0.03 & 0.19 & 1.40 & 0.02 \\
\hline \multicolumn{8}{|l|}{ No Production } \\
\hline CLOVER RUN@ @WY21 BR @ ST. GEORGE WV & 229 & 0.03 & 0.00 & 0.00 & 0.01 & 4.91 & 0.03 \\
\hline MINEAR RUN @ HWY 5 BR @ ST. GEORGE WV & 235 & 0.03 & 0.00 & 0.01 & 0.01 & 4.28 & 0.03 \\
\hline BECKY CR @ HWY 56 BR NR HUTTONSVILLE WV & 173 & 0.05 & 0.00 & 0.00 & NA & 6.28 & 0.04 \\
\hline TYGART VLYR @ HWY 15 BR @ VALLEY HEAD WV & 781 & 0.08 & 0.01 & NA & 0.00 & 5.50 & 0.05 \\
\hline HORSESHOE RUN @ HWY 9 BR @ LEAD MINE WV & 613 & 0.03 & 0.00 & 0.01 & 0.01 & 3.87 & 0.03 \\
\hline BUFFALO CREEK NEAR ROWLESBURG, WV & 458 & 0.04 & 0.00 & 0.00 & 0.02 & 4.65 & 0.05 \\
\hline N FK BLACKWATER R @ HWY 27 BR @ COKETON WV & 589 & 0.14 & 0.02 & 0.04 & 0.13 & 2.95 & 0.04 \\
\hline GLADYFK @ HWY 33 BR @ ALPENA WV & 165 & 0.02 & 0.02 & 0.01 & 0.07 & 3.00 & 0.04 \\
\hline SANDY CR @ HWY 92/14 BR @ EVANSVILLE WV & 1020 & 0.15 & 0.40 & 4.42 & 1.04 & 9.61 & 0.05 \\
\hline Average & 478 & 0.06 & 0.05 & 0.56 & 0.16 & 5.01 & 0.04 \\
\hline Standard Dev. & 1635 & 0.05 & 0.13 & 1.56 & 0.36 & 2.04 & 0.01 \\
\hline \multicolumn{8}{|l|}{ Not Used for Analysis } \\
\hline INDIAN CR @ HWY 45/2 BR @ OSGOOD WV & 350 & 3.21 & 0.00 & 0.01 & 0.02 & 7.28 & 0.02 \\
\hline INDIAN CREEK AT CROWN, WV & 326 & 4.47 & 0.00 & 0.00 & 0.01 & 10.10 & 0.02 \\
\hline
\end{tabular}


TABLE 1 (Continued) - Analytical Results

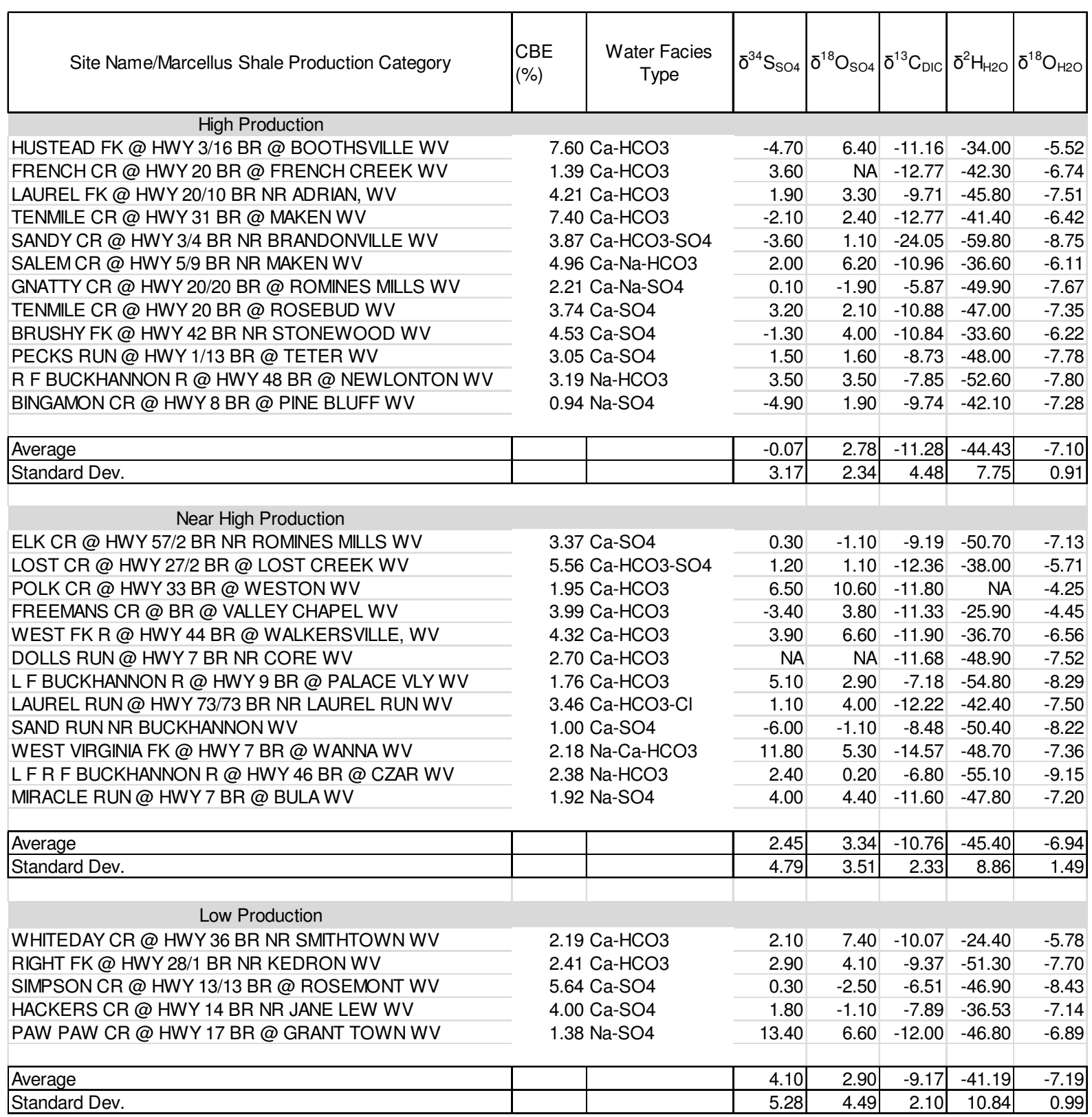


TABLE 1 (Continued) - Analytical Results

\begin{tabular}{|c|c|c|c|c|c|c|c|}
\hline Site Name/Marcellus Shale Production Category & $\begin{array}{l}\text { CBE } \\
(\%)\end{array}$ & $\begin{array}{l}\text { Water Facies } \\
\text { Type }\end{array}$ & $\delta^{34} \mathrm{~S}_{\mathrm{SO} 4}$ & $\delta^{18} \mathrm{O}_{\mathrm{SO} 4}$ & $\delta^{13} C_{D I C}$ & $\delta^{2} \mathrm{H}_{\mathrm{H} 2 \mathrm{O}}$ & $\delta^{18} \mathrm{O}_{\mathrm{H} 2 \mathrm{O}}$ \\
\hline \multicolumn{8}{|l|}{ Near Low Production } \\
\hline LEADING CR @ HWY 3 BR NR KERNS WV & \multicolumn{2}{|c|}{$2.51 \mathrm{Ca}-\mathrm{HCO} 3$} & 2.20 & 5.30 & -11.66 & -39.70 & -7.17 \\
\hline CHENOWETH CR @ HWY 23 BR @ ELKINS AIRPORT & \multicolumn{2}{|c|}{$1.76 \mathrm{Ca}-\mathrm{HCO} 3$} & -7.60 & 2.20 & -10.81 & -45.00 & -8.72 \\
\hline FILES CR @ HWY 219 BR @ BEVERLY WV & \multicolumn{2}{|c|}{$0.44 \mathrm{Ca}-\mathrm{HCO} 3$} & 0.90 & 4.60 & -12.09 & -53.80 & -8.83 \\
\hline SALTLICK CR @ RR BR @ ROWLESBURG WV & \multicolumn{2}{|c|}{$1.87 \mathrm{Ca}-\mathrm{HCO} 3$} & 1.30 & 3.70 & -9.92 & -49.83 & -8.62 \\
\hline MLL CR @ HWY 46 BR @ MILL CREEK WV & \multicolumn{2}{|c|}{$5.76 \mathrm{Ca}-\mathrm{HCO} 3$} & 4.70 & 5.50 & -7.72 & -50.50 & -8.46 \\
\hline PRICKETTS CR @ HWY73 BR @ MEADOWDALE WV & \multicolumn{2}{|c|}{$4.30 \mathrm{Ca}-\mathrm{HCO} 3$} & -3.40 & 3.60 & -10.00 & -38.10 & -6.01 \\
\hline TETER CR @ HWY 92 BR NR NESTORVILLE WV & \multicolumn{2}{|c|}{$3.53 \mathrm{Ca}-\mathrm{HCO} 3$} & -1.00 & 4.50 & -7.48 & -50.10 & -8.51 \\
\hline DECKERS CR @ HWY 27 BR @ REEDSVILLE WV & \multicolumn{2}{|c|}{$0.02 \mathrm{Ca}-\mathrm{SO} 4$} & 4.00 & 1.80 & -24.61 & -40.16 & -6.70 \\
\hline ROARING CREEK AT NORTON, WV & \multicolumn{2}{|c|}{$-1.11 \mathrm{Ca}-\mathrm{SO} 4$} & -0.90 & -6.40 & ND & -51.50 & -9.32 \\
\hline PYLES FK @ HWY 250/5 BR NR METZ WV & \multicolumn{2}{|c|}{$2.54 \mathrm{Na}-\mathrm{HCO} 3$} & 2.60 & 6.40 & -14.14 & -43.10 & -7.12 \\
\hline \multicolumn{3}{|l|}{ Average } & 0.28 & 3.12 & -12.05 & -46.18 & -7.95 \\
\hline Standard Dev. & & & 3.69 & 3.64 & 5.15 & 5.66 & 1.10 \\
\hline \multicolumn{8}{|l|}{ No Production } \\
\hline CLOVER RUN@ @ HWY 21 BR @ ST. GEORGE WV & \multicolumn{2}{|c|}{$5.37 \mathrm{Ca}-\mathrm{HCO} 3$} & 3.80 & 3.90 & -10.13 & -48.60 & -8.61 \\
\hline MINEAR RUN @ HWY 5 BR @ ST. GEORGE WV & \multicolumn{2}{|c|}{$0.84 \mathrm{Ca}-\mathrm{HCO} 3$} & 3.60 & 4.10 & -9.30 & -48.40 & -8.43 \\
\hline BECKY CR @ HWY 56 BR NR HUTTONSVILLE WV & \multicolumn{2}{|c|}{$2.48 \mathrm{Ca}-\mathrm{HCO} 3$} & NA & NA & -11.23 & -50.40 & -7.77 \\
\hline TYGART VLY R @ HWY 15 BR @ VALLEY HEAD WV & \multicolumn{2}{|c|}{$2.24 \mathrm{Ca}-\mathrm{HCO} 3$} & 1.00 & 4.40 & -10.34 & -54.80 & -8.56 \\
\hline HORSESHOE RUN @ HWY 9 BR @ LEAD MINE WV & 0.36 & $\mathrm{Ca}-\mathrm{HCO} 3$ & 2.00 & 3.20 & -8.16 & -52.80 & -8.75 \\
\hline BUFFALO CREEK NEAR ROWLESBURG, WV & \multicolumn{2}{|c|}{$-1.85 \mathrm{Ca}-\mathrm{HCO} 3$} & 1.40 & 4.50 & -9.46 & -46.30 & -8.90 \\
\hline N FK BLACKWATER R @ HWY 27 BR @ COKETON WV & \multirow{2}{*}{\multicolumn{2}{|c|}{$\begin{array}{l}5.71 \mathrm{Ca}-\mathrm{HCO} 3 \\
4.19 \mathrm{Ca}-\mathrm{HCO} 3\end{array}$}} & -0.80 & -0.20 & -6.32 & -47.50 & -8.59 \\
\hline GLADY FK @ HWY 33 BR @ ALPENA WV & & & 3.90 & 3.90 & -9.13 & -45.00 & -9.46 \\
\hline SANDYCR @ HWY 92/14 BR @ EVANSVILLE WV & \multicolumn{2}{|c|}{$-14.86 \mathrm{Ca}-\mathrm{SO} 4$} & 0.40 & -3.30 & ND & -48.90 & -8.55 \\
\hline Average & \multicolumn{2}{|l|}{0.50} & 1.91 & 2.56 & -9.26 & -49.19 & -8.62 \\
\hline Standard Dev. & \multicolumn{2}{|l|}{6.26} & 1.74 & 2.82 & 1.50 & 3.08 & 0.44 \\
\hline \multicolumn{8}{|l|}{ Not Used for Analysis } \\
\hline INDIAN CR @ HWY 45/2 BR @ OSGOOD WV & \multirow{2}{*}{\multicolumn{2}{|c|}{$\begin{array}{l}-1.07 \mathrm{Na}-\mathrm{SO} 4 \\
-0.96 \mathrm{Na}-\mathrm{SO} 4\end{array}$}} & 11.50 & 4.90 & -9.52 & -54.70 & -7.73 \\
\hline INDIAN CREEK AT CROWN, WV & & & 12.10 & 5.70 & -8.80 & -54.20 & -8.15 \\
\hline
\end{tabular}


TABLE 2 - Water facies type and their occurrence in each production category

\begin{tabular}{|c|c|c|c|c|c|c|}
\hline & & \multicolumn{5}{|c|}{ Production Category } \\
\hline & & $\begin{array}{c}\text { High } \\
\text { Production }\end{array}$ & $\begin{array}{l}\text { Near High } \\
\text { Production }\end{array}$ & $\begin{array}{c}\text { Low } \\
\text { Production }\end{array}$ & $\begin{array}{c}\text { Near Low } \\
\text { Production }\end{array}$ & $\begin{array}{c}\text { No } \\
\text { Production }\end{array}$ \\
\hline \multirow{8}{*}{$\begin{array}{l}\text { Water } \\
\text { Facies }\end{array}$} & $\mathrm{Ca}-\mathrm{HCO}_{3}$ & 4 & 5 & 2 & 7 & 8 \\
\hline & $\mathrm{Ca}-\mathrm{SO}_{4}$ & 3 & 2 & 2 & 2 & 1 \\
\hline & $\mathrm{Na}-\mathrm{HCO}_{3}$ & 1 & 1 & & 1 & \\
\hline & $\mathrm{Na}-\mathrm{SO}_{4}$ & 1 & 1 & 1 & & \\
\hline & $\mathrm{Ca}-\mathrm{Na}-\mathrm{HCO}_{3}$ & 1 & 1 & & & \\
\hline & $\mathrm{Ca}-\mathrm{Na}-\mathrm{SO}_{4}$ & 1 & & & & \\
\hline & $\mathrm{Ca}-\mathrm{HCO}_{3}-\mathrm{Cl}$ & & 1 & & & \\
\hline & $\mathrm{Ca}-\mathrm{HCO}_{3}-\mathrm{SO}_{4}$ & 1 & 1 & & & \\
\hline
\end{tabular}

